Dariusz Jarosz

Instytut Historii Polskiej Akademii Nauk, Warszawa

\title{
Zanieczyszczenie wód i powietrza w Polsce w latach 1945-1970 jako problem władzy i społeczeństwa*
}

Zarys treści: Artykułzawiera próbęodpowiedzi na pytanie, jakproblem zanieczyszczenia wódipowietrza w Polsce był traktowany przez władze Polski i społeczeństwo w latach 1945-1956. Przedmiotem analizy są: dyskurs na ten temat, ustawodawstwo o ochronie środowiska naturalnego oraz jego praktyczne funkcjonowanie, tworzenie i rozwój struktur organizacyjnych, które zajmowały się kontrolą stanu zanieczyszczeń powietrza i wód, początki świadomości ekologicznej społeczeństwa polskiego.

Słowa kluczowe: ochrona środowiska, ekologia w Polsce po II wojnie światowej, skażenie i zanieczyszczenie wody, zanieczyszczenie powietrza

Keywords: environment protection, ecology in Poland after WWII, contamination and pollution of waters, air pollution

Jeżeliby zastanowić się nad tym, w jaki sposób problemy zanieczyszczenia środowiska naturalnego są obecne w pracach historyków zajmujących się PRL, to trudno nie odnieść wrażenia, że temat ten poruszany jest incydentalnie, przy okazji rozpatrywania „wielkich” problemów politycznych. Ruchy ekologiczne lat siedemdziesiątych i osiemdziesiątych XX w. są postrzegane głównie przez pryzmat antykomunistycznego oporu i opozycji ${ }^{1}$. O degradacji środowiska wzmiankuje się przy okazji krytyki „cudu gospodarczego” okresu gierkowskiego i pogarszania jakości życia ${ }^{2}$. Prace mające ambicje syntez tej problematyki są bardzo ogólne, niepoparte głębszymi kwerendami archiwalnymi ${ }^{3}$. Wydaje się jednak, że obecnie

* Artykuł powstał w ramach projektu, który został sfinansowany ze środków Narodowego Centrum Nauki przyznanych na podstawie decyzji numer DEC-2015/17/B/HS3/00170.

${ }^{1}$ Zob. m.in. B. Hicks, Environmental Politics in Poland. A Social Movement Between Regime and Opposition, New York 1996.

2 A. Friszke, Polska. Losy państwa i narodu 1939-1989, Warszawa 2003, s. 322.

${ }^{3}$ A. Delorme, Antyekologiczna spuścizna totalitaryzmu. Polityka - gospodarka - środowisko naturalne, Kraków 1995. 
zainteresowanie tymi zagadnieniami wzrasta i ta jedna z wielu „białych plam” w historiografii dziejów najnowszych zostanie usunięta ${ }^{4}$.

Problem degradacji środowiska naturalnego w Polsce rzecz jasna nie narodził się po 1945 r., miał swoją dłuższą historię. Pomijając jego rozpatrywanie z perspektywy „długiego trwania” (trudne wobec braku podstawowych badań), warto spróbować zastanowić się nad sposobem traktowania kwestii degradacji środowiska $\mathrm{w}$ okresie szczególnie trudnym do zbadania (ze względu na braki źródłowe) - w latach 1945-1970.

Przedstawione rozważania na ten temat są obwarowane dwoma zastrzeżeniami. Po pierwsze, dotyczą głównie (choć nie tylko) okresu gomułkowskiego. Jak postaram się udowodnić, to wtedy dyskurs na ten temat wyszedł poza wąskie kręgi najwyższej władzy, zyskał na znaczeniu i objął opinię publiczną. To wówczas opracowane zostały podstawowe zręby ustawodawstwa mającego zapobiegać zanieczyszczaniu środowiska. Po drugie, w swych wywodach ograniczyłem się do problemów wody (ściślej - wód powierzchniowych) i powietrza atmosferycznego jako tych elementów środowiska, których degradacja była szczególnie groźna, powszechna i wpływająca na inne jego elementy ${ }^{5}$.

\section{Lata 1945-1953}

Tuż po wojnie problem zanieczyszczeń wody był poruszany w prasie specjalistycznej. Wskazywano w niej nie tylko na skutki gospodarcze pogarszającego się stanu czystości rzek, ale również na konsekwencje biologiczne dla społeczeństwa

\footnotetext{
${ }^{4}$ Do takiej opinii skłania mnie udział w dwóch międzynarodowych i jednej krajowej konferencjach naukowych, na których wygłoszono referaty świadczące o zainteresowaniu szeroko pojętą problematyką ekologii, w tym wpływem zanieczyszczenia środowiska na zdrowotność. Pierwsza z nich pt. „The History of Health and Disease in Central and Eastern Europe after 1945” była zorganizowana w Warszawie w dniach 14-15 X 2015; druga, zatytułowana „Nie tylko Czarnobyl. Ekologiczne wymiary historii komunizmu" odbyła się w Poznaniu w dniach 21-22 IV 2016; trzecia obradowała w Sobótce („Ochrona i wykorzystanie zasobów środowiska naturalnego na ziemiach polskich na przestrzeni wieków) w dniach 20-22 V 2016 r. Druk materiałów pokonferencyjnych wzbogaci naszą wiedzę na tematy ochrony i degradacji środowiska naturalnego.

${ }^{5}$ Kwestie te w potocznym rozumieniu są kojarzone z pojęciem ekologii. Warto jednak zaznaczyć, że pojawiło się ono w 1869 r. (jego autorem był niemiecki biolog Ernest Haeckel) i oznaczało naukę, zajmującą się całokształtem oddziaływań między zwierzętami a środowiskiem, zarówno ożywionym, jak i nieożywionym. W dzisiejszym rozumieniu ekologia jest nauką o związkach między organizmami a środowiskiem. Zob. m.in. S. Wiąckowski, Ekologia ogólna, Bydgoszcz-Kielce 2008, s. 13-20; E. Pyłka-Gutowska, Ekologia z ochrona środowiska. Przewodnik, Warszawa 1996, s. 11-15; T. Umiński, Ekologia. Środowisko. Przyroda. Podręcznik dla szkót średnich, Warszawa 1996, s. 12-13. W tym sensie przedmiot jej zainteresowania jest bardzo szeroki, co skutkowało wyodrębnieniem się wielu działów tej nauki. $Z$ tego powodu w niniejszym tekście posługuję się bardziej precyzyjnymi pojęciami jak: degradacja, ochrona i zanieczyszczenie środowiska naturalnego. Używam również określeń: świadomość ekologiczna i katastrofa ekologiczna jako zakorzenionych zarówno w języku potocznym, jak i naukowym.
} 
wycieńczonego z powodu wojny. W sposób typowy dla tamtego okresu pisał na ten temat Bronisław Rudziński w periodyku „Gaz, Woda i Technika Sanitarna” w 1946 r.: „Nasze zaopatrzenie wodne było złe [przed wojną] i jest obecnie jeszcze gorsze". Palącym zagadnieniem i obowiązkiem miało być dostarczenie ludności wody z „dotychczasowych rozporządzalnych źródeł, ale doszczętnie pozbawionej bakterii chorobotwórczych, jaj pasożytów i bakterii pochodzenia kałowego. Stan fizyczny naszego społeczeństwa jest silnie osłabiony wskutek długoletnich wstrząsów wojennych i złego odżywiania, a warunki higieniczne w jakich żyjemy w miastach i osiedlach, dotkniętych działaniami wojennymi lub perfidną siłą niszczycielską wroga, są tego rodzaju, że używana przez nas codziennie woda, nawet z lekka zakażona, wywołuje pośrednio lub bezpośrednio swe zgubne następstwa w przyspieszonym tempie i w skali wyższej, aniżeli bywało dawniej. Mówiąc o pośrednim wpływie wody na zdrowie ludzkie, mam na myśli przede wszystkim fakt zaopatrywania naszych miast $\mathrm{w}$ mleko rozrzedzone wodą, której zarazki znajdują w mleku dobrą pożywkę i szybko się rozmnażają tak, że mleko staje się źródłem groźnej infekcji, a zwłaszcza dla niemowląt, pomijając, że prawie 40\% mleka pochodzi od krów gruźliczych"'.

Ten ton prasy specjalistycznej, poruszającej temat degradacji środowiska, zmienił się w sposób charakterystyczny na przełomie lat czterdziestych i pięćdziesiątych. Świadczy o tym chociażby artykuł Adolfa Joszta, profesora Politechniki Śląskiej z 1952 r., w którym pisał on, że przymus oczyszczania ścieków „stosowany dla ochrony rzek wygląda [...] zupełnie odmiennie w różnych ustrojach społecznych, w krajach kapitalistycznych rządzi tu tylko gra interesów, a wszakże kosztowne to oczyszczanie ścieków nie jest wcale «dobrym interesem» - szczególnie, jeśli miałby to być «interes» kapitału obcego i wrogiego danemu krajowi. Tymczasem w ustroju sprawiedliwości społecznej, w ustroju socjalistycznym, ośrodkiem troski ustawodawczej jest sam człowiek. Wobec tego, dopiero w takim ustroju sprawa ochrony rzek staje się rzeczą istotną i nieodzownie konieczną, gdyż ma na celu wspólne dobro każdego obywatela. Dzisiejszy fatalny stan czystości naszych rzek - szczególnie na śląskim terenie - jest właśnie spowodowany dziesiątkami lat karygodnego zaniedbania w kapitalistycznym ustroju i jego, także i pod tym względem, rabunkowej gospodarki. Dziś więc stoi przed nami ogromne zadanie doprowadzenia naszych rzek do stanu normalnego. Jest to na Śląsku zadanie tym ogromniejsze, że w lawinowym rozwoju naszego przemysłu i zaludnienia naszej części kraju w Planie 6-letnim, rosną także niemal z dnia na dzień ilości ścieków, z którymi musimy sobie poradzić i to w sposób jak najbardziej planowy i racjonalny"7.

\footnotetext{
${ }^{6}$ B. Rudziński, Zagadnienie dobrej wody, jako warunek dobrego zdrowia, „Gaz, Woda i Technika Sanitarna" 1946, nr 1, s. 20-21.

${ }^{7}$ A. Joszt, Ochrona rzek, „Gaz, Woda i Technika Sanitarna” 1952, nr 1, s. 21-24.
} 
W okresie stalinizmu dyskurs władz o zanieczyszczeniach wody i powietrza był utajniony, ograniczony do wąskiego kręgu osób z centralnych struktur partii i państwa. Podejmowano go wtedy, kiedy sytuacja lokalnie pogarszała się na tyle, że stanowiła poważne zagrożenie dla ciągłości produkcji i zdrowia pracowników. Tak było w przypadku wielu zakładów przemysłowych, gdzie skażenie powietrza w halach produkcyjnych było na tyle duże, że powodowało liczne choroby i znaczny uszczerbek na zdrowiu (co zresztą traktowano nie w kategoriach zanieczyszczenia środowiska, ale bezpieczeństwa i higieny pracy, i co podlegało innym regulacjom prawnym).

Jako przykład mogą posłużyć przypadki zatruć dwusiarczkiem węgla $\left(\mathrm{CS}_{2}\right)$ w polskich fabrykach sztucznego jedwabiu, które były przedmiotem zainteresowania Komisji Sejmowych: Zdrowia oraz Pracy i Opieki Społecznej w 1949 r. ${ }^{8}$ Podstawą do dyskusji były m.in. referaty przygotowane przez specjalistów. Wskazali oni, że problem nie był nowy. Wystąpił już przed wojną w dwóch fabrykach jedwabiu sztucznego: w Wilamowie pod Tomaszowem Mazowieckim i w Chodakowie. W okresie okupacji sprawa zatruć CS 2 przybrała „potworne rozmiary” z powodu wybudowania przez niemiecki koncern Zellgarn nowej fabryki sztucznego jedwabiu w Łodzi w nieprzystosowanych budynkach Widzewskiej Manufaktury. Ludność robotnicza ochrzciła ją mianem „fabryki śmierci”. W okresie powojennym udało się zebrać, na podstawie kart leczenia, informacje o 144 przypadkach zatruć $\mathrm{CS}_{2}$, leczonych przez łódzkich neurologów w latach 1941-1943, a prawdziwa ich liczba była prawdopodobnie kilkakrotnie wyższa. W okresie powojennym zostało uruchomionych pięć fabryk sztucznego jedwabiu (w Wilamowie, Łodzi, Chodakowie, Wrocławiu i Szczecinie). Trzy pierwsze zostały objęte badaniami Państwowego Zakładu Higieny, dzięki czemu można było uściślić informacje na temat wpływu zatruć tą substancją na organizm ludzki. Okazało się, że $\mathrm{CS}_{2}$ jest silnym jadem wpływającym na układ nerwowy, co objawia się: brakiem sił, zmęczeniem, słabością kończyn utrudniającą chodzenie, zaburzeniami czucia nerwów obwodowych, mrowieniem, ziębnięciem kończyn, zmianami degeneracyjnymi w substancji szarej mózgu. Praca w zakładach sztucznego jedwabiu powodowała uszkodzenia rogówki i stany zapalne trwające kilka dni. Przy ostrym zatruciu $\mathrm{CS}_{2}$ występowały powtarzające się ataki szału, niedokrwistość, zmiany w jądrach z osłabieniem libido, u kobiet - sterilitas (niepłodność) i frigiditas (oziębłość płciowa), zakłócenie miesiączkowania oraz częste poronienia. Ofiary zatruć cierpiały na zaburzenia pamięci, bezsenność nocną obok skłonności do zasypiania w pracy9.

\footnotetext{
${ }^{8}$ AAN, SU, 288, Protokół wspólnego posiedzenia Komisji: Zdrowia oraz Pracy i Opieki Społecznej z 11 I 1949, k. 124-133. Szerzej - zob. D. Jarosz, Początki zainteresowania władz PRL zanieczyszczeniem powietrza (diagnozy, działania i ich efekty), referat wygłoszony na konferencji: „Ochrona i wykorzystanie zasobów środowiska naturalnego na ziemiach polskich na przestrzeni wieków”, Sobótka 20-22 V 2016 [w druku].

${ }^{9}$ AAN, SU, 288, Protokół wspólnego posiedzenia Komisji...
} 
Informacje o badaniach przeprowadzonych $\mathrm{w}$ fabrykach sztucznego jedwabiu w Łodzi i Tomaszowie Mazowieckim, zachowane w aktach Państwowej Komisji Planowania Gospodarczego (PKPG) wskazują, że skażenie dotyczyło nie tylko samych zakładów, ale również ich okolic. Z poufnego opracowania z $1950 \mathrm{r}$. wynikało, że przy samych zakładach szkodliwe stężenia gazów przekraczały często granicę uznaną w Związku Socjalistycznych Republik Radzieckich za dopuszczalną w zakładach pracy. Poziom hemoglobiny wśród włókniarek i włókniarzy zatrudnionych w pobliżu fabryk sztucznego jedwabiu był niższy niż w przypadku zatrudnionych $\mathrm{w}$ większej odległości od takich zakładów. W obu miastach ludność skarżyła się na liczne dolegliwości, które były związane z działaniem oparów dwusiarczku węgla: bóle głowy, nudności, utratę łaknienia, bezsenność. Skargi te pojawiały się w okresach, gdy wiały wiatry wschodnie, niosące zapach dwusiarczku węgla. W cytowanym opracowaniu stwierdzano, że brak jest badań na temat wpływu tego gazu na układ nerwowy. Nie dysponowano również pracami na temat sposobów oczyszczenia powietrza $z$ tej substancji. W tej sytuacji stwierdzano, że fabryki sztucznego jedwabiu powinny być budowane na obszarach podgórskich, gdzie wieją wstępujące wiatry, a odległość fabryki od osiedli ludzkich winna wynosić co najmniej $2 \mathrm{~km}^{10}$.

$\mathrm{Na}$ zanieczyszczenia powietrza i wody powodowane przez pracę tych fabryk skarżyły się władze miejskie. W piśmie Miejskiej Komisji Planowania Gospodarczego (MKPG) w Łodzi do PKPG (na ręce ministra Stefana Jędrychowskiego) z 20 grudnia 1950 pisano, że Zakłady Przemysłu Bawełnianego „1 Maja” na Bałutach produkują włókna sztuczne metodą, „której proces technologiczny, niedość rozpracowany, powoduje $\mathrm{w}$ konsekwencji $\mathrm{z}$ jednej strony poważne straty gospodarcze, z drugiej obniżenie poziomu stanu zdrowotnego mieszkańców miasta". Dwie trzecie wyprodukowanych związków siarki trafiało do atmosfery, powodując stałe zatruwanie większej części miasta. Reszta związków była odprowadzana w ściekach siecią kanałów miejskich, co spowodowało całkowite zanieczyszczenie głównego kolektora, jak również bocznych wlotów kanałowych. Alarmowano, że w lipcu 1950 r. zakłady powiadomiły MKPG o projektowanej budowie specjalnego kanału długości $10-16 \mathrm{~km}$, dostosowanego jedynie do odprowadzenia „własnych” ścieków do rzek Olechówki lub Neru. Rozwiązanie to, jak oceniano, zamieni je w cuchnące ścieki, co ze względu na kierunek panujących wiatrów groziło spotęgowaniem zatrucia powietrza nie tylko dzielnic przyległych, ale też śródmieścia ${ }^{11}$.

Jak widać, problem szkodliwości produkcji sztucznego jedwabiu był znany odpowiednim władzom, ale środki zaradcze, jakie proponowano, trudno uznać za

${ }^{10}$ AAN, PKPG, 1852, Irena Kęsy, Zanieczyszczenie powietrza dwusiarczkiem węgla w otoczeniu fabryk sztucznego jedwabiu [1950] (opracowanie poufne), b.pag.

${ }^{11}$ AAN, PKPG, 1852, Prezydium Rady Narodowej m. Łodzi, Miejska Komisja Planowania Gospodarczego do PKPG na ręce ministra dr. Stefana Jędrychowskiego, Łódź 20 XII 1950, b.pag. 
skuteczne. Poza rytualnymi zwrotami o konieczności zbadania zagadnienia, zastanawiano się nad budową studni głębinowych zaopatrujących te zakłady w wodę, specjalnego kanału ściekowego z zainstalowanym oczyszczalnikiem i wysokich, stumetrowych kominów odprowadzających trujące gazy. W tym ostatnim przypadku problem tkwił jednak w tym, że trudno było znaleźć w Polsce wykonawcę takich konstrukcji ${ }^{12}$.

Za pogłębiającą się degradacją środowiska naturalnego nie nadążała ówczesna legislacja. Obowiązująca ustawa wodna z 19 września 1922 r. (z późniejszymi nowelizacjami) z powodu braku zarządzeń wykonawczych była w zasadzie martwa, mało skuteczne były również inne przedwojenne akty prawne obowiązujące po 1945 r., dotyczące ochrony środowiska. Najważniejszą regulację tej problematyki $\mathrm{w}$ stalinizmie stanowiło rozporządzenie ministra gospodarki komunalnej z 2 września 1950 r. w sprawie określenia warunków, jakim winny odpowiadać ścieki wpuszczane do zbiorników wód powierzchniowych i do ziemi ${ }^{13}$. Na jego podstawie m.in. wprowadzono kategorie czystości wód powierzchniowych. To w tym rozporządzeniu po raz pierwszy zdefiniowano pojęcie ścieków. W powszechnej opinii zainteresowanych resortów nie było ono jednak przestrzegane - tak jak wiele innych aktów prawnych (i to nawet przez przedsiębiorstwa podległe resortowi, który je wydał) ${ }^{14}$.

O ile kwestie zanieczyszczenia wód mimo wszystko doczekały się jakiejś ułomnej legislacji, to brak jest (w tym okresie) aktów prawnych regulujących kwestie jakości powietrza atmosferycznego. Najwcześniejsze z nich pojawiają się dopiero w latach sześćdziesiątych, podobnie zresztą jak ustawodawstwo o ochronie roślin uprawnych i ziemi ${ }^{15}$. Brakowało struktur organizacyjnych i ludzi o specjalistycznym wykształceniu ${ }^{16}$.

Świadomość potrzeb w tym zakresie powoli torowała sobie drogę w myśleniu władz. Efektem tego procesu było powołanie w 1954 r. Państwowej Inspekcji Ochrony Wód (PIOW), podporządkowanej Ministerstwu Gospodarki Komunalnej $(\mathrm{MGK})^{17}$.

12 AAN, PKPG, 1852, Departament Techniki PKPG do ministra Jędrychowskiego, tajne, 5 III 1951, b.pag.

${ }^{13}$ Dz.U. 1950, nr 41, poz. 371.

${ }^{14}$ AAN, MŻiGW, 156, Inż. Jan Krysiński, Ustawodawstwo o ochronie wód przed zanieczyszczeniem, Warszawa 4 VI 1958; ibidem, MŻiGW, 59, Cz. Wdowiak, Prawna ochrona wód przed zanieczyszczeniem w Polsce, Poznań 1960. Referat wygłoszony przez autora na ogólnokrajowej naradzie pracowników służby wodno-prawnej województw w Rzeszowie, Poznań, luty 1960, b.pag.

${ }^{15}$ E. Orzeszko, System prawny ochrony środowiska w Polsce, w: System ochrony środowiska w Polsce, red. A. Klich, Wrocław 1978, s. 35.

${ }^{16}$ AAN, PKPG, 6661, Sprawozdanie rzeczowe Sekretarza Międzywojewódzkiego Komitetu Ochrony Rzek w Katowicach za rok 1951, b.pag.

${ }^{17}$ MP 1954, nr A-69, poz. 863, Uchwała Prezydium Rządu nr 436 z 7 VII 1954 o Państwowej Inspekcji Ochrony Wód; MP 1954, nr 119, poz. 1680, Zarządzenie Ministra Gospodarki Komunalnej 


\section{Problem zanieczyszczenia środowiska a destalinizacja i gomułkowska stabilizacja ${ }^{18}$}

\section{II.1. Pierwsze symptomy zmian}

Istotne zmiany pod tym względem dokonały się po wpływem destalinizacji i po dojściu do władzy Władysława Gomułki.

Po pierwsze, o problemach tych zaczęto mówić szerzej w strukturach władzy i to również w oparciu o coraz liczniejsze badania naukowe. Oto np. w 1957 r. na forum Międzyresortowej Komisji do spraw Odfenolowania Ścieków Przemysłowych zostało przedstawione studium, przygotowane w Centralnym Zarządzie Przemysłu Hutniczego, na podstawie danych zebranych z 260 zakładów odprowadzających tego typu ścieki. Wynikało z niego, że co najmniej $30 \%$ zawartych w nich fenoli trafiało do zbiorników publicznych, 9,8\% wpuszczano bezpośrednio do rzek w zlewni Wisły, do zlewni Odry - aż 46,7\%, a do innych zlewni niemal $100 \%{ }^{19}$.

Wyniki badań częściej publikowała specjalistyczna prasa, w której zaczęto się również spierać o sposoby zmiany tej sytuacji ${ }^{20}$.

Po drugie, stan środowiska naturalnego stał się tematem, którym zaczęły interesować się niektóre z koncesjonowanych, ale zdobywających z trudem pewien margines swobody organizacji społecznych. Jako przykład może służyć sprawa „Memoriału w sprawie gospodarki wodnej na zakładach przemysłowych

z 29 X 1954 w sprawie organizacji, szczegółowego zakresu działania oraz zasad i trybu postępowania Państwowej Inspekcji Ochrony Wód; Stan zanieczyszczenia rzek w Polsce. Opracowanie syntetyczne, red. K. Matul et al., Warszawa 1965, s. 6.

${ }^{18} \mathrm{~W}$ tym fragmencie artykułu wykorzystałem ustalenia zawarte $\mathrm{w}$ skróconej formie $\mathrm{w}$ tekście „Zanieczyszczenie środowiska w Polsce w latach 1956-1970 jako problem władzy”, przekazanym do druku w przygotowywanym tomie zawierającym opracowania przedstawione $\mathrm{w}$ trakcie wzmiankowanej już wcześniej konferencji „Nie tylko Czarnobyl. Ekologiczne wymiary historii komunizmu" (Poznań, 21-22 IV 2016).

19 AAN, MŻiGW, sygn. 195, Międzyresortowa Komisja do spraw Odfenolowania Ścieków Przemysłowych, Studium nad ściekami zafenolowanymi z zakładów przemysłowych i usługowych Polski oraz sposobami oczyszczenia tych ścieków, opracował inż. Jan Biczysko, Centralny Zarząd Przemysłu Hutniczego, listopad 1957, b.pag.

${ }^{20}$ Zob. m.in. S. Bontemps, W sprawie zanieczyszczeń wód, „Gospodarka Rybna” 1955, nr 2, s. 6-8; I. Cabejszek, B. Koziorowski, Z. Malanowski, J. Stanisławska, Charakterystyka higieniczno-sanitarna rzeki Wisty na odcinku Góra Kalwaria - Warszawa, „Gaz, Woda i Technika Sanitarna” 1956, nr 5, s. 175-181; F. Chrzanowski, Zanieczyszczenie wód śródlądowych województwa gdańskiego, Gospodarka Rybna” 1956, nr 7, s. 7-8; J. Trendota, W sprawie właściwych metod ochrony wód przed zanieczyszczeniem ściekami, „Gaz, Woda i Technika Sanitarna” 1956, nr 4, s. 142-143. Od 1953 r. zaczął wychodzić organ Komitetu Ekologicznego Polskiej Akademii Nauk „Ekologia Polska”, który jednak w pierwszych latach ukazywania się w zasadzie ograniczał się do tekstów ściśle naukowych, niepodejmujących problemu zanieczyszczeń środowiska naturalnego. 
województwa stalinogrodzkiego" z 2 lipca 1955 r. ${ }^{21}$ Był on efektem prac powstałej w efekcie obrad w dniach 20-21 kwietnia tego roku konferencji naukowo-technicznej, zwołanej z inicjatywy Oddziału Naczelnej Organizacji Technicznej (NOT) w Katowicach, na której po dyskusji uchwalono powołanie Komisji Międzystowarzyszeniowej z zadaniem prowadzenia akcji mającej na celu usprawnienie gospodarki wodnej i ściekowej przez zwalczanie istniejących trudności oraz opracowanie odpowiednich wniosków. Na naradzie roboczej 28 czerwca opracowano wskazany memoriał. Przede wszystkim opisywał on główne problemy gospodarki wodnej w Górnośląskim Okręgu Przemysłowym (GOP). Pisano w nim m.in., że ze względu na zanieczyszczenie ściekami „wody rzeczne, nawet większych rzek odpływających z GOP nie mogą być użyte do szeregu celów przemysłowych i rolniczych, a zakłady, które poprzednio korzystały z wód rzecznych, zmuszone są $\mathrm{w}$ niektórych wypadkach zrezygnować $\mathrm{z}$ tych wód. Tego rodzaju sytuacja dodatkowo obciąża wodociągi wody pitnej i pogłębia deficyt". Zanieczyszczone były nie tylko małe rzeczki, które "przekształciły się w rowy odpływowe”, ale i duże rzeki, które utraciły naturalną zdolność samooczyszczania. Rozpuszczone w wodzie związki chemiczne (szczególnie w Przemszy i Kłodnicy) powodowały korozję urządzeń przemysłowych.

Autorzy memoriału twierdzili, że gospodarka wodna nie jest należycie zorganizowana. Brakuje wyodrębnionej profesjonalnej służby wodnej, wyposażonej w odpowiednie urządzenia pomiarowe, kontrolne i sygnalizacyjne oraz podręcznych „laboratoriów wodnych” do monitorowania jakości wody. Uważali, że gospodarka ściekowa albo jest w ogóle bezpańska, albo w najlepszym wypadku powierzona niższemu personelowi jako czynność dodatkowa i uboczna. Planowane inwestycje, mające na celu usprawnienie gospodarki wodnej i ściekowej, są marginalizowane i w przypadku redukcji kosztów w pierwszym rzędzie skreślane. Przy budowie nowych zakładów i rozbudowie istniejących inwestycje zawiązane z oczyszczaniem ścieków i gospodarką wodną odsuwa się na dalszy plan. Często uruchamia się nowe zakłady bez wykonania inwestycji związanych z oczyszczaniem ścieków, względnie z racjonalną rozbudową gospodarki wodnej, łamiąc istniejące prawo.

Autorzy memoriału postulowali, aby powołać „centralny, ponad resortowy, urząd gospodarki wodnej”, analogicznie do istniejących w Niemieckiej Republice Demokratycznej (NRD) i Czechosłowacji, z organami terenowymi. Proponowali wyodrębnienie w resortach gospodarczych służby gospodarki wodnej i jej obsadę przez siły fachowe szkolone na politechnikach i w technikum gospodarki wodnej, które należało powołać. Inne dezyderaty dotyczyły zorganizowania na Górnym Śląsku Instytutu Przemysłowej Gospodarki Wodnej, działającego w strukturach Polskiej Akademii Nauk (PAN).

${ }^{21}$ Omówienie memoriału - na podstawie: AAN, PKPG, 8384, Memoriał w sprawie gospodarki wodnej na zakładach przemysłowych województwa stalinogrodzkiego, Stalinogród 2 VII 1955, b.pag. 
Trudno powiedzieć, na ile treść memoriału miała wpływ na działania władz. Wiadomo, że został przekazany przez pełnomocnika przewodniczącego PKPG dla spraw gospodarki wodą - przewodniczącemu PKPG Eugeniuszowi Szyrowi ${ }^{22}$. Lektura akt PKPG z 1956 r. wskazuje, że zainteresowanie władz państwowych gospodarka wodną na Górnym Śląsku (zresztą nie tylko tam) wzrosło. W aktach pojawiają się dokumenty sygnowane przez zapewne wówczas powołanego pełnomocnika przewodniczącego PKPG do spraw inwestycji wodnych na Górnym Śląsku ${ }^{23}$. Dostawy wody dla miast GOP stały się tematem konferencji na najwyższych szczeblach władzy ${ }^{24}$.

Wszystkie przytoczone argumenty wskazują, że o degradacji środowiska w drugiej połowie lat pięćdziesiątych mówiono i pisano coraz więcej i coraz krytyczniej $\mathrm{w}$ kręgach władzy, jak również $\mathrm{w}$ niektórych zorganizowanych środowiskach społecznych.

\section{II.2. Nowa legislacja, nowe urzędy}

Pochodzące z tych różnych źródeł sygnały o pogarszającym się stanie środowiska, który odbijał się negatywnie na wynikach gospodarczych i zdrowotności, zmuszały władze do podjęcia środków zaradczych.

Na mocy ustawy z 28 maja 1957 r. powstał urząd Ministra Żeglugi i Gospodarki Wodnej (DzU nr 31, poz. 130), który miał się m.in. zająć „sprawowaniem nadzoru nad ochroną wód przed zanieczyszczeniem oraz nad całokształtem gospodarki ściekowej" 25 . Podporządkowano mu PIOW ${ }^{26}$. Odpowiednie terenowe organy kontrolne (17 wojewódzkich i dwie miejskie inspekcje ochrony wód) znalazły się w strukturach tworzonych od drugiej połowy $1958 \mathrm{r}$. Wydziałów Gospodarki Wodnej (WGW) przy Prezydiach Wojewódzkich Rad Narodowych (WRN) (i dwóch miast wydzielonych). Powstało kilkanaście laboratoriów wody i ścieków przy wydziałach gospodarki wodnej ${ }^{27}$. Wydziały gospodarki wodnej po uchwaleniu ustawy z 21 kwietnia 1966 r. o ochronie powietrza atmosferycznego

22 AAN, PKPG, 8384, Pełnomocnik Przewodniczącego PKPG dla spraw gospodarki wodą do E. Szyra, przewodniczącego PKPG, Stalinogród 1 VIII 1955, b.pag.

${ }^{23}$ Zob. m.in. AAN, PKPG, 6340, Pełnomocnik Przewodniczącego PKPG do spraw Inwestycji Wodnych na G. Śląsku do Przewodniczącego PKPG wiceprezesa RM dr. St. Jędrychowskiego, 3 VIII 1956, b.pag.

${ }^{24}$ Zob. m.in.: AAN, PKPG, 6340, Notatka z konferencji, która odbyła się w dniu 23 II 1956 w Biurze Pełnomocnika Przewodniczącego PKPG dla spraw gospodarki wodą w Stalinogrodzie w sprawie zwiększenia dostawy wody dla miasta Dąbrowy Górniczej, b.pag.

${ }^{25}$ AAN, MŻiGW, sygn. 156, Ustawa z dnia 28 V 1957 o utworzeniu urzędu Ministra ŻiGW, b.pag.

${ }^{26}$ AAN, MŻiGW, 156, Inż. J. Krysiński, Ustawodawstwo o ochronie...

27 AAN, CUGW, 5, t. 2, Analiza i ocena działalności służb ochrony wód przed zanieczyszczeniem, Warszawa lipiec 1965, b.pag.; W. Brzeziński, Ochrona prawna biologicznego środowiska człowieka, Warszawa 1971, s. 178. 
przed zanieczyszczeniem (o czym piszę dalej) zostały przekształcone w Wydziały Gospodarki Wodnej i Ochrony Powietrza (WGWiOP) ${ }^{28}$. W 1960 r. utworzono Instytut Gospodarki Wodnej, w skład którego wszedł Centralny Zakład Ochrony Wód we Wrocławiu i pięć podległych mu terenowych zakładów.

Uwieńczeniem tych przemian organizacyjnych było powstanie w $1960 \mathrm{r}$. Centralnego Urzędu Gospodarki Wodnej (CUGW) jako naczelnego organu administracji (zniesiono urząd Ministra Żeglugi i Gospodarki Wodnej), podporządkowanego bezpośrednio Prezesowi Rady Ministrów (istniał do 1972 r. $)^{29}$. W jego strukturach od 1964 r. utworzono stanowisko Głównego Inspektora Ochrony Wód działającego z upoważnienia Prezesa CUGW ${ }^{30}$, a od 1966 r. - Radę Ochrony Powietrza Atmosferycznego (jako organ doradczy) ${ }^{31}$. Od 1966 r. zarządzeniem prezesa CUGW najważniejsze prace badawcze i pomiarowe w zakresie rozprzestrzeniania się zanieczyszczeń w powietrzu atmosferycznym powierzono Państwowemu Instytutowi Hydrologiczno-Meteorologicznemu. W strukturach Urzędu utworzono Biuro ds. Ochrony Powietrza Atmosferycznego ${ }^{32}$.

Stopniowo wzrastały kadry zajmujące się problematyką ochrony wód i powietrza w terenie. Do 1962 r. we wszystkich WGW (tworzonych najpierw we wszystkich województwach i miastach wydzielonych) stworzono 21 laboratoriów badania wód i ścieków. W latach 1960-1964 powołano również 116 rejonowych WGW przy prezydiach powiatowych (dzielnicowych) rad narodowych. Wojewódzkie Inspektoraty Ochrony Wód (terenowe organy PIOW) przy wszystkich PWRN zatrudniały na koniec 1964 r. 47 inspektorów oraz 327 pracowników w 21 laboratoriach badania wody i ścieków, w tym 203 pracowników inżynieryjno-technicznych $^{33}$. W 1970 r. w WGWiOP zatrudniano po jednym inspektorze ds. ochrony powietrza, z wyjątkiem Katowic, gdzie pracowało ich czterech, oraz Krakowa,

${ }^{28}$ Zob. Dz.U. 1966, nr 18, poz. 115, Rozporządzenie Rady Ministrów z 17 V 1966 r. zmieniające rozporządzenie z dnia 24 XI 1961 r. w sprawie zasad tworzenia wydziałów przez prezydia rad narodowych.

${ }^{29}$ J. Krysiński, Węzłowe problemy ochrony czystości wód (organizacyjne, techniczno-ekonomiczne i prawne), „Gospodarka Wodna” 1961, nr 10, s. 416-420; Dz.U. 1960, nr 29, poz. 163, Ustawa z 14 VI 1960 r. o utworzeniu Centralnego Urzędu Gospodarki Wodnej i przekształceniu urzędu Ministra Żeglugi i Gospodarki Wodnej w urząd Ministra Żeglugi.

${ }^{30}$ AAN, CUGW, 823, Informacja Głównego Inspektora Ochrony Wód o działalności w zakresie ochrony wód przed zanieczyszczeniem za rok 1965 oraz kierunki działania, Warszawa, grudzień 1965, b.pag.

31 Zarządzenie nr 59 Prezesa Rady Ministrów z 21 IX 1966 r. w sprawie utworzenia Rady Ochrony Powietrza Atmosferycznego przy CUGW (niepublikowane; przedruk - Ochrona powietrza atmosferycznego przed zanieczyszczeniem (przepisy i objaśnienia). Według stanu prawnego na dzień 1 czerwca 1968, red. W. Tarasiewicz, Warszawa 1968, s. 83-84.

32 AAN, CUGW, 57 (4/70), Opracowanie kierunków rozwoju zaplecza naukowo-badawczego CUGW w zakresie ochrony powietrza atmosferycznego [1970], b.pag.

33 AAN, CUGW 5, t. 2, Analiza i ocena działalności służb ochrony wód przed zanieczyszczeniem, Warszawa, lipiec 1965, b.pag. 
Opola, Poznania, Łodzi i m.st. Warszawy (po dwóch). Do tego czasu uruchomiono również 13 pracowni ochrony powietrza ${ }^{34}$.

Problemy stanu środowiska naturalnego stały się przedmiotem badań naukowych. Zajmowały się nimi liczne struktury PAN, choć według oceny Najwyższej Izby Kontroli (NIK) czyniły to zbyt opieszale ${ }^{35}$.

Stopniowo wzrastało wykształcenie specjalistyczne osób zajmujących się problemami zanieczyszczeń środowiska, m.in. w wyniku uruchomienia odpowiednich specjalności na niektórych politechnikach i w Wyższej Szkole Rolniczej w Olsztynie oraz techników i szkół zawodowych ${ }^{36}$.

Wskazane wyżej zmiany organizacyjne były efektem przyjmowania rozwiązań legislacyjnych znamionujących nowe podejście do problemów ochrony wód. Zapoczątkowało je wydane 23 czerwca 1954 r. zarządzenie nr 147 prezesa Rady Ministrów w sprawie zastosowania środków zapobiegawczych zanieczyszczeniu ściekami wód powierzchniowych. Zwracano w nim uwagę m.in. na konieczność przestrzegania postanowień rozporządzenia MGK z 2 września1950 r. w sprawie określenia warunków, jakim powinny odpowiadać ścieki wpuszczane do wód powierzchniowych i do ziemi ${ }^{37}$. W załączniku do zarządzenia zamieszczono wykaz zakładów, których ścieki były przyczyną najpoważniejszych zanieczyszczeń wód Wisły. Znalazło się w nim trzynaście kopalni, jedenaście hut, trzy zakłady cynkowe, dwie rafinerie nafty, dwie fabryki celulozy i papieru, dwa zakłady chemiczne i jeden kokso-chemiczny ${ }^{38}$.

20 sierpnia 1955 r. została wydana uchwała nr 668 prezydium rządu w sprawie ochrony wód przed zanieczyszczeniem oraz zapobiegania szkodliwemu działaniu ścieków i ich gospodarczego wykorzystania. Ministrowie, którym podlegały zakłady pracy odprowadzające ścieki, zostali zobowiązani do należytego rozwiązania zagadnienia ich oczyszczania w ramach kierowanych przez siebie resortów. Uchwała stanowiła, że projektowanie budowy, przebudowy albo modernizacji lub rozbudowy zakładów pracy odprowadzających ścieki do wód powierzchniowych bez racjonalnego rozwiązania zagadnienia oczyszczania zabezpieczającego przed szkodliwym działaniem ścieków jest niedopuszczalne ${ }^{39}$.

${ }^{34}$ AAN, CUGW, 69, t. VI, Bieżące problemy ochrony powietrza atmosferycznego, Warszawa, listopad 1970, b.pag.

35 AAN, NIK II, 16/201, Sprawozdanie z kontroli ochrony wód powierzchniowych przed zanieczyszczeniem i zapobiegania szkodliwemu działaniu ścieków, Warszawa, sierpień 1959, b.pag.

${ }^{36}$ AAN, CUGW 69, t. VI, CUGW, Bieżące problemy ochrony powietrza atmosferycznego, Warszawa, listopad 1970, b.pag.; AAN, NIK II, 34/212, Ministerstwo Gospodarki Terenowej i Ochrony Środowiska, Informacja o stanie środowiska w Polsce, Warszawa, kwiecień 1973, b.pag.

${ }^{37}$ AAN, MŻiGW, 156, Inż. J. Krysiński, Ustawodawstwo o ochronie...

${ }^{38}$ AAN, MŻiGW, 156, Wykaz zakładów, których ścieki są przyczyną najpoważniejszych zanieczyszczeń wody rzeki Wisły, b.pag.

${ }^{39}$ AAN, MŻiGW, 156, Inż. J. Krysiński, Ustawodawstwo o ochronie...; AAN, MŻiGW, 57, Uchwala nr 668/55 Prezydium Rządu z dnia 20 VIII 1955 r. w sprawie ochrony wód przed 
Najwięcej kontrowersji wśród zainteresowanych władz wzbudził jednak projekt ustawy o ochronie wód przed zanieczyszczeniem. Zagadnienie to, zgodnie z poleceniem prezesa Rady Ministrów z 3 czerwca 1959 r., zostało wyłączone $\mathrm{z}$ nowo opracowywanego projektu prawa wodnego i jako pilne potraktowane oddzielnie w osobnym akcie prawnym. Projekt ustawy był przedmiotem obrad rządu 31 grudnia 1959 r. i wzbudził „zasadnicze zastrzeżenia”, zwłaszcza ministra przemysłu lekkiego. Po wielu dyskusjach ustawa została uchwalona 31 stycznia $1961 \mathrm{r}^{40} \mathrm{Na}$ jej podstawie wydano rozporządzenie prezesa Rady Ministrów z 28 lutego 1962 r. określające normy dopuszczalne zanieczyszczeń wody oraz warunki, jakim powinny odpowiadać ścieki odprowadzane do wody i do ziemi. Postanowienia ustawy z 31 stycznia $1961 \mathrm{r}$. zostały włączone w wersji nieznacznie zmienionej do prawa wodnego uchwalonego 30 maja 1962 r. (DzU nr 34, poz. 158), stąd wprowadzone przez nie regulacje można scharakteryzować łącznie ${ }^{41}$.

Co było przedmiotem kontrowersji, które przedłużyły proces legislacyjny? Wymaga to dalszych badań, ale odnalezione materiały źródłowe i opracowania wskazują, że najwięcej różnic zdań powodowały przewidziane w rozwiązaniach prawnych obowiązki nakładane na zakłady pracy w zakresie budowy urządzeń do oczyszczania ścieków oraz kary nakładane na trucicieli.

Oba akty prawne posługiwały się określeniem skażenia wody (prawo wodne - „szkodliwym skażeniem wody”), definiowanym jako wywoływanie takich zmian fizycznych, chemicznych lub biologicznych przez wprowadzenie do nich nadmiernych ilości substancji lub energii, które sprawiają, że „wody nie nadają się do celów komunalnych, przemysłowych, rolniczych, rybackich lub innych". Zdaniem ówczesnego kierownictwa CUGW było to zerwaniem z dotychczasowym poglądem (obecnym w obowiązującej do $1961 \mathrm{r}$. legislacji), że wszelkie skażenie przekraczające miarę powszechnego użytkowania było szkodliwe i niedopuszczalne; wynikające $\mathrm{z}$ nich wymagania odnośnie do stopnia oczyszczania ścieków i czystości wód były raczej jednostronnym wyrazem potrzeb, szczególnie higieniczno-sanitarnych, bez uwzględnienia możliwości technicznych i ekonomicznych. Rygorystyczne i nieżyciowe wymagania obowiązujących do 1961 r. przepisów - twierdzili urzędnicy CUGW - powodowały nie tylko często nieproporcjonalny do efektów wzrost kosztów budowy urządzeń, lecz również nierzadko stwarzały niepokonane do tego czasu trudności w zakresie rozwiązań technicznych.

zanieczyszczeniem oraz zapobiegania szkodliwemu działaniu ścieków i ich gospodarczego wykorzystania, b.pag. Jej stosowanie było utrudnione ze względu na ogólnikowość lub niewydanie wielu niezbędnych aktów wykonawczych. Zob. AAN, MŻiGW, 156, Sprawozdanie Państwowej Inspekcji Ochrony Wód [po 30 VI 1957], b.pag.

${ }^{40}$ Dz.U. 1961, nr 5, poz. 33.

${ }^{41}$ W. Brzeziński, op. cit., s. 155-159; AAN, MŻiGW, sygn. 60, Notatka w sprawie projektu ustawy o ochronie wód przed zanieczyszczeniem, Warszawa 18 X 1960 [CUGW], b.pag. 
Zgodnie z tą filozofią plany ochrony wód powinny uwzględniać realne możliwości techniczne i ekonomiczne oczyszczania ścieków oraz oczywiste aktualne potrzeby użytkowników zasobów wodnych ${ }^{42}$. Zakazywano szkodliwego zanieczyszczania wód, tzn. takiego, które przekroczy stopień ich czystości przewidziany dla danej zlewni ${ }^{43}$.

Zgodnie z nowymi regulacjami wprowadzenie do wód śródlądowych (oraz morskich wód wewnętrznych i do morza terytorialnego) substancji lub energii, które mogą je szkodliwie zanieczyścić, wymagało uzyskania „pozwolenia wodno-prawnego". Było ono wydawane w oparciu o projekt obiektów budowlanych gospodarki wodnej (urządzeń oczyszczających) potrzebnych do postulowanego korzystania $\mathrm{z}$ wody i zawierać miało określenie ilości, stanu i składu odprowadzanych ścieków. $W$ razie nieprzestrzegania tych zasad pozwolenie mogło być odebrane. Zakłady, które w dniu wejścia w życie ustawy z 31 stycznia $1961 \mathrm{r}$. (9 lutego tego roku) nie posiadały wymaganych urządzeń zabezpieczających wodę przed zanieczyszczeniem, musiały zostać w nie wyposażone stopniowo, zgodnie z decyzjami Rady Ministrów podjętymi na wniosek prezesa CUGW zgłoszony w porozumieniu z przewodniczącym Komisji Planowania przy Radzie Ministrów i zainteresowanymi ministerstwami. Do tego czasu mogły one lege artis wprowadzać do wód ścieki w takiej ilości, stanie i składzie, jak w dniu 9 lutego $1961 \mathrm{r}$. i nie mogły być $z$ tego powodu karane (art. 166.6 prawa wodnego). Zakłady, które miały urządzenia zabezpieczające przed zanieczyszczeniami wody, a nie posiadały pozwoleń wodno-prawnych, zostały zobowiązane do ich uzyskania w określonym terminie. Prawo wodne przewidywało ustanowienie stref ochronnych źródeł i ujęć wody do celów konsumpcyjnych ${ }^{44}$.

Zarówno ustawa z 1961 r., jak i prawo wodne z 1962 r. zawierały przepisy karne za nadmierne zanieczyszczenie wód, wymierzane przez prokuraturę, kolegia karno-administracyjne i wydziały gospodarki wodnej (od 1966 r. i ochrony powietrza). Kary pieniężne obciążały budżet zakładu ${ }^{45}$.

Dużo mniej rozbudowana była legislacja dotycząca ochrony powietrza. 1 marca 1961 r. Rada Ministrów podjęła uchwałę (niepublikowaną) nr 91 w sprawie zmniejszenia zanieczyszczenia powietrza na terenie GOP. Analizowana wcześniej ustawa prawo wodne z 30 maja 1962 r. zawierała regulację (art. 82, ust. 4), iż jej przepisy stosuje się również przy zanieczyszczeniu powietrza w sposób, który może być przyczyną szkodliwego zanieczyszczenia wód. Niepublikowana uchwała nr 7 Rady Ministrów z 12 stycznia 1965 r. sytuowała CUGW jako organ

\footnotetext{
${ }^{42}$ Ibidem.

${ }^{43}$ S. Surowiec, Uwagi do ustawy o ochronie wód przed zanieczyszczeniem, „Gospodarka Wodna” 1961, nr 10 s. 426-427.

${ }^{44}$ W. Brzeziński, op. cit., s. 155-171.

${ }^{45}$ Ibidem, s. 187.
} 
administracji państwowej odpowiedzialny za ochronę powietrza ${ }^{46}$. Odpowiednie normatywy wydawały również ministerstwa ${ }^{47}$.

Pierwszym aktem prawnym regulującym w sposób generalny tę kwestię była ustawa z 21 kwietnia 1966 r. o ochronie powietrza atmosferycznego przed zanieczyszczeniem (DzU nr 14, poz. 87). Zgodnie z nią powietrze atmosferyczne podlegało ochronie przed zanieczyszczeniem uciążliwym dla człowieka lub wywierającym ujemny wpływ na jego zdrowie bądź na klimat, wegetację roślin, hodowlę zwierząt, wartość użytkową gleby lub wody, lub powodującym inne straty dla gospodarki narodowej (art. 1.1). Zanieczyszczenie powietrza było definiowane jako „wprowadzanie do niego substancji stałych, ciekłych i gazowych [...] w ilościach lub rodzaju, które mogą spowodować przekroczenie dopuszczalnych stężeń w powietrzu atmosferycznym” (art. 1.2). Dopuszczalne stężenia tych substancji w powietrzu miała określić Rada Ministrów w drodze rozporządzenia ${ }^{48}$. Zakłady, których działalność mogła spowodować przekroczenie tych stężeń, zobowiązane były do budowy, instalacji i eksploatacji odpowiednich urządzeń ochronnych (art. 3.1) ${ }^{49}$. Projekty planów zagospodarowania przestrzennego oraz lokalizacja zakładu, którego działalność mogła spowodować przekroczenie dopuszczalnych stężeń substancji szkodliwych w powietrzu, winny być uzgodnione $\mathrm{z}$ właściwym organem do spraw ochrony powietrza atmosferycznego (art. 4.2). Z tymże organem miał być również uzgodniony projekt wstępny budowy lub przebudowy zakładu, którego działalność mogła spowodować przekroczenie dopuszczalnych stężeń.

Ustawa umożliwiała ustanawianie stref ochronnych przed zanieczyszczeniem powietrza (art. 6.1). Zwierzchni nadzór nad organami ochrony powietrza sprawował CUGW (art. 10.2). Bezskuteczne zobowiązanie zakładu do usunięcia w określonym terminie braków lub zaniedbań w zakresie ochrony powietrza mogło spowodować wydanie decyzji o unieruchomieniu zakładu lub jego części (art. 11.1.2).

Istniejące $\mathrm{w}$ dniu wejścia $\mathrm{w}$ życie ustawy zakłady wprowadzające do powietrza substancje zobowiązane zostały do zgłoszenia do wojewódzkich organów

\footnotetext{
${ }^{46}$ A. Jaroszyński, Ochrona prawna zasobów naturalnych w PRL, Warszawa 1972, s. 167; Ochrona powietrza atmosferycznego..., s. 3-4.

${ }^{47}$ AAN, NIK II, 23/224, Kontrola wykonania uchwały nr 91/61 Rady Ministrów z dnia 1 III 1961 oraz zarządzenia nr 110/61 Ministra Górnictwa i Energetyki z 5 X 1961 r. w sprawie zmniejszenia zanieczyszczenia powietrza pyłami lotnymi i gazami, Katowice 2 X 1962, k. 157.

${ }^{48}$ Zob. Dz.U. 1966, nr 42, poz. 253, Rozporządzenie Rady Ministrów z dnia 13 IX 1966 r. w sprawie dopuszczalnych stężeń substancji w powietrzu atmosferycznym.

${ }^{49}$ Ich tworzenie regulowały: rozporządzenie Rady Ministrów z dnia 23 III 1967 r. w sprawie stref ochronnych ustanawianych dla ochrony powietrza atmosferycznego przed zanieczyszczeniem (Dz.U. 1966, nr 15, poz. 66) i zarządzenie Prezesa CUGW z dnia 30 V 1967 r. w sprawie szerokości stref ochronnych ustanawianych dla ochrony powietrza atmosferycznego przed zanieczyszczeniem (MP 1967, nr 32, poz. 152).
} 
do spraw ochrony powietrza danych dotyczących ich ilości i składu. Organy te, $\mathrm{w}$ porozumieniu $\mathrm{z}$ właściwym państwowym inspektorem sanitarnym, miały określić dla każdego zakładu rodzaj i ilość substancji „dopuszczalnych do wydalania” oraz zobowiązać je do „budowy, zainstalowania i eksploatacji odpowiednich urządzeń albo zastosowania odpowiednich środków" ochronnych i określić terminy wykonania tych obowiązków (art. 13.1 i 13.2). Kto wbrew ciążącemu obowiązkowi nie budował, nie instalował i nie eksploatował odpowiednich urządzeń ochronnych, nie stosował środków ochronnych przy utrzymywaniu hałd i wysypisk, nie wykonywał pomiarów stężeń substancji w powietrzu, nie zgłaszał danych dotyczących rodzaju lub ilości substancji, podlegał karze grzywny do 4500 zł w trybie przepisów o orzecznictwie karno-administracyjnym. Kary pieniężne, obciążające wyniki gospodarcze przedsiębiorstwa (wpływały na zmniejszenie funduszu zakładowego) miały być wymierzane za przekraczanie rodzaju i ilości substancji, dopuszczalnych „do wydalania” (art. 15.1 i 15.2). Ich wysokość i tryb ściągania miała ustalić Rada Ministrów $\left(\right.$ art. 15.3) ${ }^{50}$. Ustawa nie miała zastosowania do ochrony powietrza w pomieszczeniach zamkniętych (art. 16) ${ }^{51}$ i nie dotyczyła oddziaływania substancji promieniotwórczych (art. 17).

Ustawodawstwo $\mathrm{w}$ sprawie ochrony powietrza atmosferycznego dopełniała uchwała Rady Ministrów nr 18 w sprawie ochrony lasów przed ujemnymi wpływami szkodliwych pyłów i gazów wydzielanych przez zakłady przemysłowe (MP nr 4, poz. 33), która ustalała obowiązki tych zakładów w zakresie pokrywania kosztów specjalnej gospodarki leśnej w strefach zagrożenia wywołanego zanieczyszczeniem powietrza.

\section{II.3. Stan zanieczyszczenia wód i powietrza}

Stworzenie podstaw organizacyjno-prawnych systemu ochrony środowiska naturalnego było bez wątpienia widomą oznaką dostrzeżenia problemu przez władze państwowe. Czy podjęte działania były skuteczne i wystarczające? Na ile przyczynily się do poprawy sytuacji?

\footnotetext{
50 Zob. Dz.U. 1967, nr 40, poz. 203, Rozporządzenie Rady Ministrów z 26 IX 1967 r. w sprawie zasad określania wysokości kar pieniężnych wymierzanych zakładom za przekraczanie ilości pyłów dopuszczalnych do wydalania do powietrza atmosferycznego.

${ }^{51} \mathrm{~W}$ ich przypadku sprawy ochrony powietrza regulowała ustawa z 30 III 1965 r. o bezpieczeństwie i higienie pracy (Dz.U. 1965, nr 13, poz. 91). Zgodnie z art. 19.1 najwyższe dopuszczalne stężenie substancji szkodliwych dla zdrowia określać miały przepisy wydane przez Radę Ministrów w drodze rozporządzenia, na wniosek lub po porozumieniu z Centralną Radą Związków Zawodowych (CRZZ). Szczegółowe przepisy bezpieczeństwa i higieny pracy mogli wydawać ministrowie w porozumieniu z ministrem zdrowia i opieki społecznej i w uzgodnieniu z zarządami głównymi odpowiednich związków zawodowych.
} 
Odpowiedzi na te pytania należy szukać $\mathrm{w}$ wynikach badań przeprowadzanych w analizowanym okresie ${ }^{52}$. Dzięki stworzeniu odpowiednich służb, których zadaniem była m.in. kontrola stanu środowiska, możliwe jest, przynajmniej w ograniczonym stopniu, pokazanie zmian stanu zanieczyszczeń wód powierzchniowych i powietrza atmosferycznego.

Badania czystości rzek w latach: 1964, 1967 i 1970 zostały przeprowadzone przez Instytut Gospodarki Wodnej. Ich porównywalność jest ograniczona z tego względu, że wyniki tych badań zostały oparte o inne kryteria dla lat: 1964 i 1967, a inne dla roku 1970. Ponadto odnalezione informacje na temat tych wyników nieco się różnią dla tych samych lat. $\mathrm{W}$ dalszych analizach, $\mathrm{w}$ celu uniknięcia zbytnich komplikacji, posługuję się ustaleniami opublikowanymi przez Instytut Gospodarki Wodnej w „Atlasie zanieczyszczenia rzek” za lata: 1967 i 1970. Edycja „Atlasu” z 1967 r. zawiera dane porównawcze czystości rzek z 1964 i 1967, oparte o analizę 100 rzek kraju o łącznej długości prawie 11,5 tys. $\mathrm{km}^{2}$, z uwzględnieniem $80 \%$ rzek o powierzchni zlewni większej od $2000 \mathrm{~km}^{2}$.

$\mathrm{Z}$ zamieszczonych tam szacunków (posługujących się obowiązującą wówczas klasyfikacją czystości ${ }^{53}$ ) wynika, że stan zanieczyszczenia wód głównych rzek kraju w latach 1964-1967 utrzymywał się na podobnym poziomie. W $1967 \mathrm{r}$. w porównaniu z 1964 zasięg wód klasy V, nieodpowiadających ustalonym normatywom, zwiększył się o 26,4 km biegu rzek (z 41,2\% do 41,5\%), wód klasy III i IV - o 23,4 km (z 24,2\% do 24,4\%). Z tego powodu nastąpiło zmniejszenie zasięgu wód klasy I i II (z 34,5\% do 34,2\%). Potwierdziły to wyniki badań bardziej specjalistycznych wskaźników czystości (zawartość fenoli, zasolenie, wartość BZT5, charakteryzującego zanieczyszczenia związkami organicznymi) ${ }^{54}$.

${ }^{52}$ Te badania mogły być coraz bardziej kompleksowe i coraz dokładniejsze dzięki stworzeniu sieci punktów pomiarowych. W przypadku wód powierzchniowych w 1961 r. kontrolowano 361 odbiorników w 2464 punktach pomiarów, a w 1964 - już 506 w 2557 punktach. Do 1964 r. zbadano wszystkie rzeki o powierzchni zlewni powyżej $500 \mathrm{~km}^{2}$. Dla około $50 \% \mathrm{z}$ nich opracowano i opublikowano komunikaty o stanie czystości wód, obejmując około 68\% ich długości. W 1969 r. istniały 2692 stanowiska pomiarowe zanieczyszczeń pyłowych i 1640 gazowych, które miały trudności z zaopatrzeniem w odpowiednią aparaturę pomiarową. W tymże roku 180 zakładów miało obowiązek wykonywania pomiarów zarówno emisji, jak i stężeń w atmosferze na terenie stref ochronnych i zakładów. Zob. AAN, CUGW 5, t. 2, Analiza i ocena działalności służb ochrony wód przed zanieczyszczeniem, Warszawa, lipiec 1965, b.pag.; AAN, CUGW 69, t. VI, Bieżące problemy ochrony powietrza atmosferycznego, Warszawa, listopad 1970, b.pag. Szczegółowy opis badań prowadzonych w okresie powojennym zanieczyszczenia rzek - zob. Stan zanieczyszczenia rzek...

${ }^{53}$ Obowiązujące wówczas klasy czystości wód zostały ustalone w rozporządzeniu Prezesa Rady Ministrów z 28 lutego 1962 r. (Dz.U. 1962, nr 17, poz. 75). Zgodnie z nim klasa I obejmowała wody przydatne do: życia ryb łososiowatych; II - celów komunalnych; III - celów rolniczych; IV - celów przemysłowych. W niektórych dokumentach z tego okresu wymienia się również klasę V - ściekową.

${ }^{54}$ Atlas zanieczyszczenia rzek $w$ Polsce 1967, Warszawa 1971, s. 8 i tabl. 4 po s. 12. BZT5 - biologiczne zapotrzebowanie tlenu, to „pojęcie umowne określające ilość tlenu wymaganą do 
W 1967 r. dokonano po raz pierwszy pomiarów w czasie jesiennej kampanii produkcyjnej przemysłu rolno-spożywczego (kiedy stan czystości wód był gorszy głównie z powodu zrzucania dużych ładunków ścieków organicznych przez cukrownie) i w okresie pozakampanijnym. W tym pierwszym badania wykazały przynależność do I i II klasy - 34,2\%, do klasy III i IV - 28,1\%, a do V - 37,7\% ogólnej długości badanych rzek. W okresie pozakampanijnym odpowiednie wskaźniki wynosiły: 35,6\%, 32,1\%, 32,3\%. Najwyższy stopień obciążenia wód związkami organicznymi występował w województwach: lubelskim, katowickim, poznańskim warszawskim i wrocławskim ${ }^{55}$.

Jak do wyników uzyskanych dla lat 1964 i 1967 mają się badania dotyczące roku 1970? Jak już wzmiankowano wcześniej, problem jest skomplikowany z tego powodu, że publikowane szacunki dla tego ostatniego roku zostały oparte o nowe kryteria klasyfikacyjne, określone rozporządzeniem Rady Ministrów z 9 czerwca 1970 r. w sprawie norm dopuszczalnych zanieczyszczeń wód i warunkach wprowadzania ścieków do wody i do ziemi ${ }^{56}$. Dla celów porównawczych dokonano przeliczenia odpowiednich wartości zanieczyszczeń dla 1967 r. na nowe kryteria klasyfikacyjne dla długości rzek wynoszącej $8640,4 \mathrm{~km}$. Stwierdzono, że między 1967 a 1970 r. nastąpiło dalsze zmniejszenie wód klasy I o 575,3 km (6,7\%) w okresie kampanii jesiennej i o 706,6 km $(8,2 \%)$ w okresie pozakampanijnym oraz zwiększenie wód klas niższych (od 186,1 km do 310,5 km w zależności od okresu i klasy) ${ }^{57}$.

Przedstawione dane, przy wszystkich zastrzeżeniach dotyczących ich porównywalności, zdają się wskazywać, że w latach 1967-1970, w stosunku do okresu

utlenienia związków organicznych. Wskaźnik określa pośrednio stężenie substancji organicznych ulegających biodegradacji (bioutlenieniu). Przekroczenie normy BZT5 oznacza, że woda zawiera nadmiar związków organicznych, co może powodować niedobór tlenu i w konsekwencji śmierć organizmów, dla których jest on niezbędny do życia (np. ryb)”. Za: http://www.zb.eco.pl/gh/4/ bzt_p.htm (dostęp: 30 I 2017).

${ }^{55}$ AAN, CUGW 69, t. VII, Informacja dotycząca a) ograniczenia stopnia zanieczyszczenia wód powierzchniowych; b) budowy oczyszczalni ścieków; c) zakładania stref ochronnych ujęć wodnych [czerwiec 1971], b.pag. Nieco inne dane na temat czystości wód zbadanych w 1967 - zob. Ochrona wód powierzchniowych przed zanieczyszczeniem. Raport końcowy, t. 1, Wrocław 1971, s. 44 , tab. 16.

${ }^{56}$ Rozporządzenie ustanawiało cztery klasy stężenia wskaźników zanieczyszczeń w zależności od celów użytkowania (klasa I - zaopatrzenie ludności w wodę do picia, zaopatrzenie przemysłu spożywczego i innych przemysłów wymagających wody do picia, hodowla ryb łososiowatych; klasa II - hodowla ryb, z wyjątkiem łososiowatych, zaspokojenie potrzeb hodowli zwierząt gospodarskich, urządzenie zorganizowanych kąpielisk, uprawianie sportów wodnych; klasa III zaopatrywanie przemysłów z wyjątkiem przemysłów wymagających wody do picia, nawadnianie terenów rolniczych, wykorzystywanych do upraw ogrodniczych oraz upraw pod szkłem; klasa IV - wody nieodpowiadające normatywom). Zob. Atlas zanieczyszczenia rzek $w$ Polsce 1971, Warszawa 1972, s. 8.

${ }^{57}$ Atlas zanieczyszczenia rzek w Polsce 1970, Warszawa 1972, s. 142-145. 
1964-1967, stan czystości wód uległ pogorszeniu. Mimo że w rzekach silnie zanieczyszczonych zmniejszyły się bezwzględne wartości mierzonych stężeń zanieczyszczeń, to i tak były one wyższe od dopuszczalnych, a więc nie miały wpływu na poprawę klasyfikacji ${ }^{58}$.

W przypadku powietrza atmosferycznego określenie stanu zanieczyszczeń jest jeszcze trudniejsze z powodu mniejszego niż w przypadku wody zaawansowania badań. Kontrole NIK przeprowadzone w 1962 r. w zakładach i zjednoczeniach podległych resortowi górnictwa i energetyki wykazały, że powszechnie brakowało nie tylko urządzeń odpylających, ale również zestandaryzowanych mierników zanieczyszczenia powietrza ${ }^{59}$. W tej sytuacji ocena skali zagrożenia jest utrudniona.

Ze wstępnych szacunków, dokonanych w 1965 r. przez stacje sanitarno-epidemiologiczne wynika, że najbardziej zagrożone z powodu zanieczyszczenia powietrza były województwa: katowickie i wrocławskie oraz miasto Łódź; stopień zagrożenia średni miał cechować Kraków, Warszawę, województwa: bydgoskie, łódzkie, opolskie i poznańskie. Pozostała część kraju (63\% obszaru i 46\% ogółu mieszkańców) miała być w niewielkim stopniu narażona na „złe” powietrze ${ }^{60}$.

Z oceny sytuacji dokonanej przez CUGW w 1970 r. wynika, że w 1966 r. emisja dwutlenku siarki do atmosfery wynosiła około $2 \mathrm{mln}$ ton, tzn. niewspółmiernie dużo w porównaniu $\mathrm{z}$ największymi gospodarkami świata (w USA - 28 $\mathrm{mln}$ ton). Zanieczyszczenia pyłowe szacowano wówczas na 4-5 mln ton rocznie. Największe nasycenie powietrza zanieczyszczeniami przemysłowymi w końcu lat sześćdziesiątych odnotowano na osi Siersza - Gliwice oraz w okolicach wielkich zakładów takich jak: Nowa Huta, Huta Bieruta w Częstochowie, cementownie w Opolu i w Nowinach, Zakłady Azotowe w Puławach, Zakłady Rafineryjne i Petrochemiczne w Płocku, Huty Aluminium w Skawinie i Koninie oraz Zagłębie Siarkowe w rejonie Tarnobrzega. Powierzchnię zniszczonych i uszkodzonych lasów w wyniku zanieczyszczeń powietrza szacowano w Polsce na 240 tys. ha, tj. około 3\% powierzchni kraju. Sytuacja w Śląsko-Krakowskim Okręgu Przemysłowym była gorsza niż w innych rejonach na świecie na skutek poważnej rozbudowy przemysłu przy utrzymywaniu w ruchu wielu przestarzałych zakładów pochodzących nawet z XIX w. (koksownie, cynkownie itp.) ${ }^{61}$.

\footnotetext{
${ }^{58}$ A. Leńkowa, Aktualny stan zagrożenia środowiska $w$ Polsce, w: Prawo a ochrona środowiska, red. L. Łustacz, Wrocław-Warszawa 1975, s. 29-31; Atlas zanieczyszczenia rzek w Polsce 1970..., s. $144-145$.

${ }^{59}$ AAN, NIK II, 23/224, Protokół kontroli Jaworznicko-Mikołowskiego Zjednoczenia Przemysłu Węglowego w Mysłowicach przeprowadzonej w okresie 2-7 VIII 1962, k. 89-93; ibidem, Protokół kontroli rybnickiego Zjednoczenia Przemysłu Węglowego w Rybniku w okresie od 27 VII do 2 VIII 1962, k. 81-87.

${ }^{60}$ AAN, KC PZPR, 237/XIV-345, Ministerstwo Zdrowia i Opieki Społecznej, Ocena realizacji wskaźników planu służby zdrowia i opieki społecznej na lata 1961-1965, s. 87.

${ }^{61}$ AAN, CUGW, 69, t. VI, Bieżące problemy ochrony powietrza atmosferycznego, Warszawa, listopad 1970, b.pag.
} 
Na podstawie opracowanych przez CUGW w 1969 r. bilansów 311 zakładów "produkujących” najwięcej zanieczyszczeń (60\% emisji krajowej), zlokalizowanych w 59 rejonach, szacowano ich ilość na 2100 tys. ton pyłów (spadek o $4 \%$ w stosunku do 1968 r.) i 1290 tys. ton dwutlenku siarki (wzrost o blisko 7\%). Ze sprawozdawczości CUGW wynika, że w latach 1967-1970 uzyskiwano ograniczenie emisji pyłów, ale jednocześnie wzrastała emisja gazów do atmosfery. Wynikało to z rozbudowy przemysłu emitującego te gazy i braku skutecznych metod ich redukcji ${ }^{62}$.

\section{II.4. Bariery poprawy sytuacji}

\section{II.4.1. Urządzenia, ludzie, pieniądze}

Jak wynika z poczynionych ustaleń, bitwę o czyste (a ściślej: czystsze) wody i powietrze w latach 1956-1970 trudno uznać za zakończoną zwycięstwem. Złożyło się na to wiele przyczyn.

Jedną z pierwszych prób analizy stanu ochrony wód i przyczyn ich zanieczyszczeń była zbiorcza kontrola NIK z 1958 r., która objęła kilkaset urzędów i przedsiębiorstw podległych różnym resortom, których problem ścieków szczególnie dotyczył.

Stwierdzono, że do zakładów odprowadzających ścieki bez oczyszczenia, względnie niedostatecznie oczyszczone należały przede wszystkim:

- kopalnie węgla kamiennego, zakłady przemysłu kokso-chemicznego i zakłady hutnicze zanieczyszczające rzeki w województwach katowickim i wrocławskim;

- zakłady przemysłu chemicznego, zanieczyszczające wody w zasadzie w całym kraju (w tym Wisłę: zakłady chemiczne w Oświęcimiu i w Łęgnowie k. Bydgoszczy; Odrę: m.in. Nadodrzańskie Zakłady Przemysłu Organicznego „Rokita” w Brzegu Dolnym; Bóbr: Jeleniogórskie Zakłady Celulozy i Włókien Sztucznych);

- zakłady przemysłu lekkiego zanieczyszczające liczne zbiorniki wód zwłaszcza na terenie Łodzi oraz w województwach katowickim i wrocławskim;

- zakłady przemysłu spożywczego, szczególnie w województwach: wrocławskim, bydgoskim i poznańskim; dotyczyło to przede wszystkim przemysłu cukrowniczego, który w okresie kampanii cukrowniczej zanieczyszczał rzeki i jeziora w całym kraju;

- zakłady przemysłu celulozowo-papierniczego, zanieczyszczające rzeki m.in. na terenie województw: katowickiego, bydgoskiego i opolskiego;

${ }^{62}$ AAN, CUGW, 511, Sprawozdanie z działalności CUGW za rok 1968, Warszawa, styczeń 1969, k. 25-26; AAN, CUGW, 512, Sprawozdanie z działalności CUGW za rok 1970, k. 6-8; AAN, CUGW, 57 (6/70), Analiza realizacji polityki państwowej w zakresie ochrony powietrza atmosferycznego przed zanieczyszczeniem za rok 1969, Warszawa, maj 1970, b.pag. 
- zakłady gospodarki komunalnej, zanieczyszczające rzeki ściekami z gospodarstw domowych i różnych zakładów odprowadzających ścieki do kanalizacji miejskiej;

- zakłady lecznictwa zamkniętego (szpitale, sanatoria), które odprowadzały groźne dla wód powierzchniowych ścieki w stanie nie tylko nieoczyszczonym, ale bardzo często i bez dezynfekcji.

Niejednokrotnie zanieczyszczenia były spowodowane awaryjnym jednorazowym zrzutem wód ściekowych (jak np. w czerwcu 1959 r. do rzeki Brdy przez zakłady „Persil” w Bydgoszczy).

Trwałe zanieczyszczenie wód powierzchniowych przez daną fabrykę powodowało konieczność budowy przez inne zakłady, znajdujące się poniżej źródeł zanieczyszczeń, urządzeń do uzdatniania wody. I tak kopalnia „Andaluzja”, nieoczyszczająca swoich wód dołowych i poposadzkowych, zmuszała elektrownię kopalni "Jowisz" do oczyszczania wód pobieranych z Brynicy. Podobna sytuacja miała miejsce na Czarnej Przemszy: niejednokrotnie zakłady przemysłowe, zmuszone do oczyszczania wód, odprowadzały z kolei również nieoczyszczone ścieki i powodowały konieczność uzdatniania wody w innych zakładach położonych w dalszym biegu danego odbiornika ${ }^{63}$.

Rozmiary zanieczyszczeń były niekiedy tak poważne, że uniemożliwiały korzystanie $\mathrm{z}$ istniejących urządzeń do poboru wody lub też powodowały, że woda mimo uzdatniania nie odpowiadała warunkom wymaganym w procesie produkcji, względnie do spożycia w gospodarstwach domowych. I tak np. wskutek zanieczyszczenia wód Białej Przemszy przez Fabrykę Celulozy i Papieru w Kluczach nie wykorzystywano wówczas w ogóle wybudowanego jeszcze przed wojną ujęcia wody w Maczkach o zdolności produkcyjnej ok. 120 tys. $\mathrm{m}^{3}$ wody na dobę. Ujęcie to jeszcze w latach 1947-1949 produkowało około 66 tys. $\mathrm{m}^{3}$ wody na dobę i zostało unieruchomione w wyniku rozbudowy zakładów w Kluczach bez rozwiązania sprawy oczyszczania ścieków. Mieszkańcy Wrocławia byli zaopatrywani w wodę o niedostatecznej jakości z ujęcia na Oławie, która była zanieczyszczona ściekami przemysłowymi z zakładów przemysłowych, zwłaszcza przemysłu cukrowniczego w okresie kampanii cukrowniczych. Zamulenie kanału i portu gliwickiego na skutek odprowadzania do rzeki Kłodnicy nieoczyszczonych wód popłuczkowych, przede wszystkim przez kopalnie węgla kamiennego, utrudniało jego żeglowność. Ze zbadanych w trakcie kontroli 124 zakładów lecznictwa zamkniętego tylko cztery odkażały ścieki w stopniu dostatecznym, wymaganym przepisami.

${ }^{63} \mathrm{O}$ praktyce zmuszania zakładów do budowy własnych oczyszczalni ścieków lub zmiany rzeki, z której jest pobierana woda do produkcji z powodu działalności innego zakładu - truciciela, pisała Krystyna Zielińska (Dziwna zabawa, „Polityka” 1964, nr 15, s. 5 ): „Żywieckie piwo jak najgorzej wpływało na żywiecki papier. Na skutek działalności piwowarów - Zakłady Papiernicze musiały zaplanować na Sole budowę stacji «uzdatniania» wody”. 
Kontrola NIK wskazała, że w pierwszych latach powojennych urządzenia do oczyszczania ścieków często nie były eksploatowane, a te, których używano rzadko konserwowano. Według orientacyjnej oceny MGK na 217 oczyszczalni w kraju podległych temu resortowi -69 , tj. 30\%, wymagało remontów lub odbudowy w celu przywrócenia im właściwej sprawności eksploatacyjnej. Koszt remontu szacowano na ok. $15 \mathrm{mln}$ zł. Podobnie było w innych resortach. W wielu oczyszczalniach nie uzyskano możliwego technicznie stopnia oczyszczania ze względu na niewłaściwą eksploatację i zły stan techniczny urządzeń. Części z nich nie eksploatowano mimo dostatecznego stanu technicznego.

NIK kwestionowała efektywność nakładów inwestycyjnych na budowę czy modernizację wielu oczyszczalni. Niektóre z nich były wykonane wadliwie, budowa innych opóźniała się z braku środków finansowych, dokumentacji technicznej i „możliwości przerobowych” wykonawców. Kontrolerzy stwierdzili, że technologia oczyszczania wielu kategorii ścieków nie jest w Polsce znana, względnie stosowane metody nie są dostatecznie sprawne, w tym m.in. związków fenolowych i innych składników chemicznych ${ }^{64}$.

Podobnie pesymistyczne wnioski płynęły z 1740 kontroli gospodarki wodnej i ściekowej w zakładach przemysłowych przeprowadzonych w latach 1954-1958 przez organa PIOW w całym kraju ${ }^{65}$.

Przytoczone ustalenia znalazły potwierdzenie w różnych kontrolach cząstkowych, przeprowadzanych na początku lat sześćdziesiątych. Dokonana w 1961 r. lustracja 253 istniejących oczyszczalni ścieków w miejskich zakładach wodociągowych i kanalizacyjnych wykazała, że tylko 104 posiadało urządzenia do mechanicznego i biologicznego oczyszczania ścieków, 101 - kompletne urządzenia do mechanicznego oczyszczania, 38 - jedynie niektóre elementy mechanicznego oczyszczania, a 10 było nieczynnych od 1945 r. i zdewastowanych. We wszystkich z nich stopień redukcji zanieczyszczeń był niedostateczny i nie odpowiadał wymogom przepisów o ochronie wód. Nawet tam, gdzie odpowiednie urządzenia pracowały, były często niefachowo eksploatowane głównie na skutek braku nadzoru technicznego i kwalifikacji zatrudnionych pracowników. Wieloletnie zaniedbania powodowały, że przepustowość i wydajność urządzeń wybudowanych przed 1939 r. była za mała, a te, które wybudowano po wojnie, cechowały się niskim poziomem wykonawstwa ${ }^{66}$.

Kolejna zbiorcza kontrola NIK z 1966 r. potwierdziła, że wskazane już wcześniej niedociągnięcia i nieprawidłowości nie tylko przyczyniały się do trwałego

\footnotetext{
${ }^{64}$ AAN, NIK II, 16/201, Sprawozdanie z kontroli ochrony wód powierzchniowych przed zanieczyszczeniem i zapobiegania szkodliwemu działaniu ścieków, Warszawa, sierpień 1959, s. 1-18.

${ }^{65}$ AAN, MŻiGW, 199, Ogólna ocena stanu technicznego i skutków eksploatacji urządzeń do oczyszczania ścieków oraz ujęć wodnych w przemyśle [1958], b.pag.

${ }^{66}$ AAN, CUGW, 833, Charakterystyka stanu, działania i wykorzystania komunalnych oczyszczalni ścieków, b.pag.
} 
zanieczyszczenia wód powierzchniowych, ale również zmuszały do budowy dużych obiektów wodociągowych w znacznej odległości od ośrodków, które zaopatrywały w wodę.

Charakterystycznym przykładem była budowa ujęcia wody dla GOP w Czańcu na Sole, kosztem ok. 1 mld zł z uwagi na niemożność wykorzystania lokalnych źródeł. Trudno się temu dziwić, skoro w województwie katowickim na ogólną długość rzek wynoszącą $993 \mathrm{~km}$, zaledwie $71 \mathrm{~km}, \mathrm{tj} .7,2 \%$ odpowiadało w połowie lat sześćdziesiątych warunkom życia biologicznego; na długości $541 \mathrm{~km}, \mathrm{tj} .54,6 \%$, ilość ścieków w stosunku do wód własnych spowodowała, że rzeki te przybierały charakter kanałów ściekowych. Podobne rozwiązanie - pobieranie wody z Raby na skutek niemożności zaopatrzenia z zanieczyszczonej Wisły - zastosowane zostało w przypadku Krakowa (od 1974 r.) ${ }^{67}$.

Kontrolerzy NIK w 1966 r. poczynili jeszcze inne alarmujące ustalenia: na 393 „zakłady zakaźne i przeciwgruźlicze” - 273 odprowadzały ścieki zazwyczaj zakażone, nieodpowiadające warunkom określonym w odpowiednim rozporządzeniu Rady Ministrów (z 28 lutego 1962 r.) do kanalizacji miejskiej (162 zakłady) lub do wód powierzchniowych (111).

Okazało się również, że wszystkie z 600 zakładów służby zdrowia odprowadzających ścieki do kanalizacji miejskiej lub lokalnej (na ogólną liczbę 969) nie oczyszczały ich, a nawet skutecznie nie odkażały. Ścieki te w większości nie były również odkażane w oczyszczalniach komunalnych.

W wielu wypadkach, m.in. na terenie województw: wrocławskiego, warszawskiego i krakowskiego, występowała zbieżność między wysokim wskaźnikiem zagruźliczenia bydła i wzrostem zachorowań na gruźlicę - w rejonach o dużym nasileniu odprowadzania ścieków bez oczyszczania i bez dezynfekcji ${ }^{68}$.

Kontrola NIK stwierdziła również, że spośród 700 oczyszczalni ścieków, jakie miały być oddane do użytku w latach 1961-1965, faktycznie przekazano tylko 511 (73\%), przy czym większość z poważnymi wadami. Oczyszczalnie były oddawane do użytku z opóźnieniem i nie odpowiadały ustalonym parametrom oczyszczania ścieków z powodu błędów, zwłaszcza w wykonawstwie.

W oficjalnych dokumentach liczba zakładów, które posiadały urządzenia do oczyszczania określona została na ok. 2100. Faktycznie była ona zawyżona, gdyż znaczna część zakładów posiadała wiele prymitywnych urządzeń do oczyszczania, które w świetle nomenklatury technicznej nie mogły być wprawdzie zaliczone do tych urządzeń, choć prawidłowa ich eksploatacja mogłaby przyczynić się do zmniejszenia zanieczyszczenia wód. Jednak nie były one właściwie eksploatowane. Normą było niewyposażanie zakładów posiadających obiekty do oczyszczania

${ }^{67}$ AAN, NIK II, 52/14, Sprawozdanie z kontroli budowy i eksploatacji urządzeń do oczyszczania ścieków oraz przestrzegania przepisów chroniących wody przed zanieczyszczeniem, Warszawa, wrzesień 1967, s. 208-212.

${ }^{68}$ Ibidem, s. 214. 
w urządzenia do pomiaru ilości ścieków. Na przykład w resorcie przemysłu lekkiego na 336 zakładów podległych dziesięciu zjednoczeniom (w tym 188 zakładów mających oczyszczalnie lub urządzenia) - tylko dwanaście było wyposażonych w aparaturę pomiarową. Brakowało fachowej kadry, regułą było nieprowadzenie nadzoru laboratoryjnego nad ściekami ${ }^{69}$.

Wiele uzupełniających informacji na ten temat można odnaleźć w dokumentach wytworzonych przez CUGW. Wynika z nich, że w latach 1961-1965 wydatkowano ponad 2,4 mld zł na budowę oczyszczalni ścieków (tj. 73\% zaplanowa-

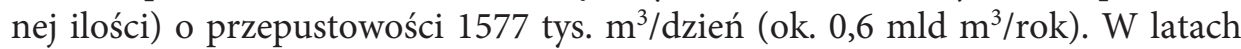
1966-1970 podniesiono nakłady na ten cel do 5,3 mld zł i przekazano do eksploatacji urządzenia do oczyszczania ścieków w 541 zakładach przemysłowych, komunalnych i innych o przepustowości $4,1 \mathrm{mln} \mathrm{m}^{3} /$ dobę, z czego oczyszczalnie mechaniczne stanowiły $74 \%$, biologiczne $12 \%$ a chemiczne $14 \%$. $62-73 \%$ nakładów na budowę oczyszczalni ścieków skoncentrowano w województwach południowych (rzeszowskie, krakowskie, katowickie, opolskie, wrocławskie), tzn. tam, gdzie zanieczyszczeń wód było najwięcej ${ }^{70}$.

Jak ten bezwzględny postęp wpłynął na proces oczyszczania wód? CUGW ustalił, że wskaźnik procentowy oczyszczanych ścieków w latach 1960-1965 utrzymywał się na podobnym poziomie $28 \%$.

Tabela 1. Zanieczyszczenia wód i ich oczyszczanie w latach 1960-1965

\begin{tabular}{|l|r|r|r|}
\hline \multirow{2}{*}{} & 1960 & 1964 & 1965 \\
\cline { 2 - 4 } & \multicolumn{3}{|c|}{ mln m $^{3}$ na rok } \\
\hline $\begin{array}{l}\text { 1. Zapotrzebowanie wody przez przemysł i gospo- } \\
\text { darkę narodową }\end{array}$ & 5271 & 6039 & 6996 \\
\hline 2. Ilość ścieków odprowadzonych & 4835 & 5825 & 6300 \\
\hline 3. Ilość ścieków oczyszczanych & 1427 & 1647 & 1750 \\
\hline 4. \% ścieków oczyszczanych & 28 & 28 & 28 \\
\hline $\begin{array}{l}\text { 5. Ilość ścieków nieoczyszczonych, a wymagających } \\
\text { oczyszczania }\end{array}$ & 1490 & 1685 & 2040 \\
\hline
\end{tabular}

Źródło: AAN, CUGW 508, CUGW w Warszawie, Sprawozdanie z działalności za rok 1965, Warszawa, styczeń 1966, k. 12.

${ }^{69}$ Ibidem, s. 215-236.

70 AAN, CUGW, 69, t. VII, Informacja dotycząca a) ograniczenia stopnia zanieczyszczenia wód powierzchniowych; b) budowy oczyszczalni ścieków; c) zakładania stref ochronnych ujęć wodnych [czerwiec 1971], b.pag.; AAN, CUGW, 69, t. VI, Informacja Prezesa CUGW w sprawie realizacji ustawy „Prawo Wodne” - ochrona wód przed zanieczyszczeniem [1970], b.pag. 
Wielkość ścieków odprowadzanych przez przemysł i gospodarkę komunalną w 1967 r. została oszacowana na 7,5 mld $\mathrm{m}^{3}$ na rok $^{71}$.

Analizując tę kwestię, warto pamiętać, iż sam fakt oczyszczania wód nie oznaczał, że zostały one dostatecznie oczyszczone. Wspomnieliśmy już wyżej, na podstawie dokumentacji kontrolnej NIK, o złym stanie istniejących oczyszczalni ścieków, ich malej przepustowości i niedostosowaniu do potrzeb. Potwierdzały to analizy przeprowadzane przez CUGW i jego terenowe agendy. W 1965 r. urząd szacował, że na ok. 12000 przemysłowych, komunalnych i innych zakładów pracy wytwarzających ścieki, około 8600 odprowadzało je bezpośrednio do rzek, jezior i do ziemi, a ok. 3400 - do systemów komunalnych sieci kanalizacyjnych. Z tej liczby ok. 2000 zakładów, tj. 17\%, posiadało oczyszczalnie ścieków. Ich działalność była z reguły nieskuteczna, bo ok. 64\% ścieków oczyszczanych było mechanicznie, a więc przeważnie niedostatecznie, a ok. 70\% ogólnej ilości oczyszczalni działało wadliwie. Tylko $22 \%$ ścieków wytwarzanych w około 2960 zakładach istotnych z punktu widzenia ochrony wód, odprowadzanych do wód powierzchniowych, było oczyszczanych i to nie zawsze w stopniu wystarczającym ${ }^{72}$. Nakłady na nowe urządzenia zwykle jako pierwsze padały ofiarą oszczędności w planach inwestycji przemysłowych $^{73}$.

W przypadku ochrony powietrza barierą podstawową był brak odpowiednich urządzeń do pomiaru skażeń, jak też do ich neutralizowania ${ }^{74}$. Te mierniki, które posiadano, miały być zgodnie z planami inwestycyjnymi, instalowane w określonej liczbie zakładów (w 1970 r. - w blisko 200), ale możliwości ich produkcji nie pokrywały potrzeb (trudności kooperacyjne). Zainstalowane urządzenia odpylające były niskiej jakości, ulegały częstym awariom, co prowadziło do nadmiernej emisji zanieczyszczeń. Poza tym warto pamiętać, że zagadnienie ochrony powietrza w latach sześćdziesiątych zostało sprowadzone w zasadzie do sprawy emisji pyłów. O wiele trudniejsza i jeszcze nawet poza Polską nierozwiązana była kwestia redukcji zanieczyszczeń gazowych, głównie szkodliwych związków siarki i azotu ${ }^{75}$.

${ }^{71}$ AAN, CUGW, 37, Informacja Departamentu Koordynacji i Planowania CUGW o obecnym stanie gospodarki wodnej w Polsce i jej zadaniach na okres do 1975 r., [przed 8 VIII 1968], b.pag.

72 AAN, CUGW, 69, t. II, [CUGW do marszałka Sejmu PRL Cz. Wycecha, kwiecień 1966], b.pag.; ibidem, Informacja o aktualnym stanie i zadaniach w zakresie ochrony wód przed zanieczyszczeniem [1967], b.pag.; AAN, URM, 2.2/127, Referat wprowadzający Głównego Inspektora Ochrony Wód, wiceprezesa CUGW ob. W. Janiszewskiego, wygłoszony w dniu 24 IX 1965 na konferencji w sprawie ochrony przed zanieczyszczeniem wód w kraju, k. 7; AAN, CUGW, 823, Informacja Głównego Inspektora Ochrony Wód o działalności w zakresie ochrony wód przed zanieczyszczeniem za rok 1965 oraz kierunki działania, Warszawa, grudzień 1965, s. 1-7.

73 T. Podwysocki, Brońmy czystej wody, „Przegląd Techniczny” 1968, nr 35, s. 1 i 10.

${ }^{74}$ AAN, CUGW, 511, Sprawozdanie z działalności CUGW za rok 1968, Warszawa, styczeń 1969, k. 25.

75 AAN, CUGW, 69, t. II, Informacja o aktualnym stanie i zadaniach w zakresie ochrony powietrza atmosferycznego, b.pag.; AAN, CUGW, 69, t. VI, CUGW, Bieżące problemy ochrony powietrza 
II.4.2. (Nie)skuteczność środków prawnych: karanie, „truciciele", katastrofy i klęski ekologiczne

Jak już wskazałem wcześniej, istniejąca legislacja pozwalała na stosowanie różnych środków, mających na celu powstrzymanie zanieczyszczania wód i - w dużo bardziej ograniczonym stopniu - powietrza. Na ile były skuteczne? Odpowiedź na to pytanie należy zacząć od konstatacji, że wskazane regulacje pozostawały $\mathrm{w}$ konflikcie z priorytetem produkcji zakładó ${ }^{76}$. W przypadku analizowanego prawa wodnego najważniejsze dylematy brzmiały następująco: „czy dopuszczalna jest odmowa pozwolenia na korzystanie $\mathrm{z}$ wód przez odprowadzanie ścieków $\mathrm{w}$ przypadku, gdy od takiego właśnie korzystania $\mathrm{z}$ wód zależy realizacja zadań planowych zakładu"77; czy to konkretne przedsiębiorstwo, a nie jego właściciel państwo, ma odpowiadać za brak urządzeń do oczyszczania ścieków? Kwestie te były przedmiotem dyskusji prawniczych ${ }^{78}$. Jak były one rozwiązywane w praktyce funkcjonowania przedsiębiorstw?

Szkodliwe zanieczyszczanie wód było przedmiotem penalizacji (zob. tab. 2). Sprawy o odszkodowania za zanieczyszczenie wód toczyły się przed komisjami arbitrażowymi i sądami. W czerwcu 1964 r. suma roszczeń wynosiła ok. 5564 tys. z779. Najwcześniejsze dokumenty na ten temat, odnalezione w analizowanych archiwaliach, pochodzą z początku lat pięćdziesiątych i dotyczą odszkodowań za masowe zatrucia ryb w wyniku spuszczania do rzek dużych ładunków zanieczyszczeńn ${ }^{80}$.

W pierwszych latach obowiązywania prawa wodnego brakowało wytycznych dotyczących jednolitych metod poboru ścieków i przeprowadzania ich analiz oraz obliczania przewidzianych $\operatorname{kar}^{81}$. Z czasem, dzięki aktom wykonawczym,

atmosferycznego, Warszawa, listopad 1970, b.pag.; AAN, CUGW, 57 (4/70), Opracowanie kierunków rozwoju zaplecza naukowo-badawczego CUGW w zakresie ochrony powietrza atmosferycznego [1970], b.pag.

${ }^{76}$ Tak formułowano to np. w oficjalnym dokumencie CUGW, przygotowanym na wyjazdowe posiedzenie jego Kolegium w Katowicach 1 i 2 III 1965 r. zatytułowanym „Informacja o głównych problemach gospodarki wodnej a w szczególności o zaopatrzeniu w wodę Śląska na tle Planu Perspektywicznego Gospodarki Wodnej Śląsko-Krakowskiego Okręgu Przemysłowego" (AAN, CUGW, 56, t. LXII, b.pag.): „Przyczyną niezadowalających efektów w zakresie uzyskania planowej czystości wód jest między innymi to, że sprawa budowy i eksploatacji urządzeń do oczyszczania i unieszkodliwiania ścieków jest przez resorty traktowana jako zadania uboczne, które zawsze ustępują na rzecz produkcji”.

77 W. Brzeziński, op. cit., s. 161.

${ }^{78}$ Ibidem, s. 161-163.

79 AAN, CUGW 69, t. I, Prezes CUGW W. Janiszewski do Marszałka sejmu Cz. Wycecha, 26 VI 1964, b.pag.

${ }^{80}$ AAN, NIK II, 16/184, Wykaz odszkodowań zapłaconych przez cukrownie wchodzące w skład Pom. Z.P.C. z tytułu szkód wyrządzonych w stanie zarybienia rzek i jezior, Toruń, 2 XII 1958, k. 81.

${ }^{81}$ AAN, CUGW, 56, t. LXVI, Informacja w sprawie stosowania nowego prawa wodnego w okresie 2 lat po jego wejściu w życie, [przed 31 XII 1964], b.pag. 
Tabela 2. Zestawienie zastosowanych w latach 1961-1967 środków prawnych w stosunku do osób i zakładów prowadzących nieprawidłowo gospodarkę ściekową

\begin{tabular}{|c|c|c|c|c|c|c|c|c|c|c|c|c|c|c|c|}
\hline \multirow[b]{2}{*}{ Okres } & \multicolumn{4}{|c|}{$\begin{array}{l}\text { Art. } 154 \text { prawa } \\
\text { wodnego } \\
\text { (stosowany przez } \\
\text { prokuraturę) }\end{array}$} & \multicolumn{4}{|c|}{$\begin{array}{c}\text { Art. } 156 \text { prawa } \\
\text { wodnego } \\
\text { (stosowany przez } \\
\text { kolegia karno- } \\
\text {-administracyjne) }\end{array}$} & \multirow[t]{2}{*}{ 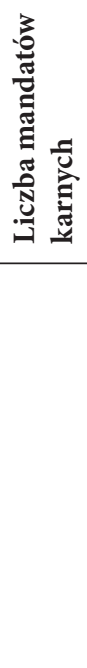 } & \multicolumn{3}{|c|}{$\begin{array}{c}\text { Art. } 160 \text { prawa } \\
\text { wodnego } \\
\text { (stosowany } \\
\text { przez } \\
\text { WGWiOP } \\
\text { PWRN) }{ }^{85}\end{array}$} & \multicolumn{3}{|c|}{$\begin{array}{c}\text { Liczba spraw } \\
\text { w postępowaniu } \\
\text { egzekucyjnym }\end{array}$} \\
\hline & 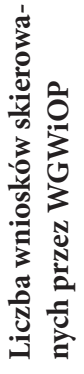 & 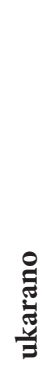 & 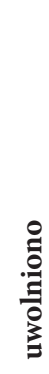 & 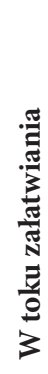 & 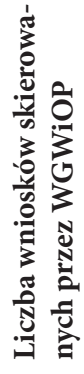 & 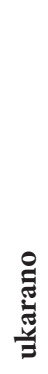 & 苗 & $\frac{\text { E⿱ }}{2}$ & & 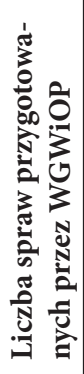 & 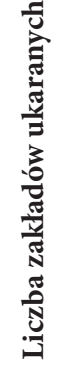 & 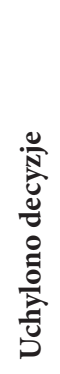 & $\frac{\text { E⿱ }}{2}$ & 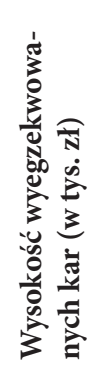 & \\
\hline $\begin{array}{l}1961- \\
1964\end{array}$ & 45 & 5 & 40 & - & 30 & 9 & 21 & - & & 35 & 24 & 11 & & 7945 & \\
\hline 1965 & 14 & 1 & 13 & - & 37 & 12 & 25 & - & & 46 & 27 & 19 & & 6898 & 11 \\
\hline 1966 & 11 & 2 & 9 & - & 23 & 8 & 15 & - & & 65 & 43 & 22 & & 12786 & 22 \\
\hline 1967 & 38 & 10 & 2 & 26 & 86 & 55 & 18 & 33 & & 207 & 90 & 23 & 94 & 33737 & 18 \\
\hline 1968 & 80 & & & & & & & & 4 & 305 & 148 & - & & 29698 & 23 \\
\hline 1969 & 53 & & & & & & & & 33 & 333 & 184 & - & & 59727 & 24 \\
\hline
\end{tabular}

Źródło: AAN, CUGW 69, t. VI, Informacja Prezesa CUGW w sprawie realizacji ustawy „Prawo Wodne” ochrona wód przed zanieczyszczeniem [1970], b.pag.; ibidem, t. II, Informacja o aktualnym stanie i zadaniach w zakresie ochrony wód przed zanieczyszczeniem [1967], b.pag.; ibidem, t. IV, Informacja Prezesa CUGW w sprawie wykonania planu gospodarki wodnej w skali krajowej oraz planu i budżetu CUGW za rok 1967, Warszawa czerwiec 1968, b.pag.

82 „Art. 154.1 Kto szkodliwie zanieczyszcza wody (art. 82 ust. 3) - podlega karze aresztu do dwóch lat i grzywny do 100000 zł. Jeżeli sprawca działa nieumyślnie - podlega karze aresztu do jednego roku lub grzywny do 50000 zł; 2. Tym samym karom podlega, kto wbrew obowiązkowi określonemu w art. 84 nie eksploatuje urządzeń zabezpieczających wody przed zanieczyszczeniem”.

83 „Kto wbrew ciążącemu na nim obowiązkowi: 1) nie ustawia i nie utrzymuje w należytym stanie znaków wodnych i wodnych urządzeń pomiarowych (art. 48 ust. 2);2) zwiększa ilość oraz zmienia stan i skład wprowadzonych do wód ścieków (art. 48 ust. 3); 3) nie utrzymuje w należytym stanie koryta wody i jej brzegów powyżej bądź poniżej piętrzącego obiektu budowlanego (art. 49); 4) nie wykonuje i nie utrzymuje w należytym stanie urządzeń zapobiegających szkodzie dla gospodarki narodowej lub obywateli (art. 51 ust 1) - podlega karze grzywny do $4500 \mathrm{zł”.}$

${ }^{84}$ „Art. 160.1 Wojewódzki organ administracji wodnej wymierzy zakładowi (art. 10 pkt 3) karę pieniężną za szkodliwe zanieczyszczenie wód; wysokość kary pieniężnej jest zależna od ilości, 
trudność ta została pokonana. Kary naliczane w wyniku podjęcia wskazanych działań prawnych były zróżnicowane regionalnie i branżowo. Stosunkowo największe nakładano na kopalnie węgla kamiennego. Oto np. w 1967 r. w zakładach podległych Ministerstwu Górnictwa i Energetyki na mocy art. 160 prawa wodnego nałożono kary w wysokości 2610 691,60 zł, z tego największą na Kopalnię Węgla Kamiennego „Dębieńsko” (2 295641 zł) ${ }^{85}$. W tym roku suma kar wyegzekwowanych z art. $160 \mathrm{w}$ całej Polsce wynosiła ponad $33 \mathrm{mln}$ zł.

Obowiązujące prawo wodne pozwalało również na nakładanie indywidualnych kar pieniężnych nie tylko na bezpośrednich sprawców zabronionych czynów, ale również na kierowników lub osoby, którym powierzono prowadzenie gospodarki wodnej w jednostkach państwowych, spółdzielczych lub społecznych (art. 158). Jaka była ich wysokość? Udało się odnaleźć tylko informacje dotyczące wybranych branż i województw. I tak np. pochodzący z marca $1968 \mathrm{r}$. wykaz dyrektorów i kierowników zakładów ukaranych grzywnami przez kolegia karno-administracyjne w województwie lubelskim zawiera jedenaście nazwisk. Największe z nich nałożono na głównego technologa Cukrowni Klemensów (3500 zł) i dyrektora Cukrowni Werbkowice $(3125 \mathrm{zł})^{86}$. Lektura akt na ten temat zdaje się potwierdzać tezę o umiarkowanej skłonności prokuratur do prowadzenia śledztw w tych sprawach. Rzadko kończyły się one wyrokami skazującymi na kary więzienia.

Na nieskuteczność penalizacji w sprawach o zanieczyszczenia wód wpływała sama konstrukcja prawa wodnego. Jak już wczesnej wzmiankowano, nie pozwalało ono na karanie ogromnej większości zakładów nieposiadających odpowiednich urządzeń - jeżeli produkowane przez nie zanieczyszczenia utrzymywały się co do ilości, stanu i składu na takim poziomie jak w dniu 9 lutego 1961 r. (art. 166.6

stanu i składu ścieków. 2. Kary pieniężne wymierza się za: 1) wprowadzenie ścieków do wód i do ziemi bez posiadania pozwolenia wodnoprawnego; 2) uruchomienie oczyszczalni ścieków lub innych urządzeń zabezpieczających wody przed zanieczyszczeniem, których działanie nie odpowiada warunkom technicznym projektu budowlanego. 3. Kary pieniężne mogą być wymierzane za: 1) niewykonanie przez zakład w ustalonym terminie budowy, rozbudowy lub przebudowy urządzeń zabezpieczających wody przed zanieczyszczeniem; 2) niewprowadzanie zmiany procesów wytwórczych wynikających z pozwolenia wodnoprawnego, a zmierzającej do obniżenia ilości zużycia wody i ładunku zanieczyszczeń odprowadzanych w ściekach z produkcji; 3) przeprowadzenie bez uzgodnienia $\mathrm{z}$ właściwym organem administracji wodnej zmiany procesów produkcyjnych zakładu, które w sposób stały wpływają na zwiększenie zanieczyszczeń wód. 4. Kary pieniężne obciążają wyniki gospodarcze zakładu. 5. Rada Ministrów ustali w drodze rozporządzenia zasady określania wysokości kar pieniężnych i tryb ich ściągania”.

${ }^{85}$ AAN, CUGW, 912, Kary z art. 160 prawa wodnego wymierzone zakładom podległym Ministerstwu Górnictwa i Energetyki, b.pag.

${ }^{86}$ AAN, CUGW, 912, Wykaz dyrektorów i kierowników zakładów ukaranych indywidualnymi karami pieniężnymi (kolegia karno-administracyjne) za szkodliwe zanieczyszczenie wód woj. lubelskie, 25 III 1968, b.pag. W 1968 r. średnia płaca w przemyśle uspołecznionym wynosiła 2447 zł. Zob. Rocznik Statystyczny GUS 1971, Warszawa 1971, s. 7, tab. I. 
prawa wodnego). Tymczasem stanowiły one $80 \%$ zakładów odprowadzających ścieki do wód powierzchniowych ${ }^{87}$.

$\mathrm{Na}$ ważne społeczne uwarunkowania tego procesu karania (a raczej bezkarności) zwracała uwagę m.in. Agata Zawieruszanka na łamach „Prawa i Życia”. Twierdziła, że w 1966 r. wszczynaniem spraw o zanieczyszczenie wód zajmowało się w praktyce 44 pracowników wojewódzkiej inspekcji ochrony wód, a pozostałych 350 pracowników inspekcji na poziomie powiatów - tylko dorywczo. „Jak przy takiej obsadzie kadrowej - 44 osoby - mówić o skuteczności kontroli nawet w województwach słabiej uprzemysłowionych?! W warunkach, gdy parę godzin opóźnienia w pobraniu zanieczyszczonej wody do analizy ma decydujący wpływ na wszczęcie śledztwa bądź jego umorzenie? W warunkach, gdy wnioskujący o ukaranie w trybie karno-administracyjnym bądź karnym jest zobowiązany do pełnego udokumentowania składanego wniosku, bowiem inaczej prokurator lekką ręką odrzuci doniesienie. Nie znam wypadku, aby prokuratury tylko na podstawie meldunku o zatruciu rzeki zadziałały natychmiast z urzędu wszczynając dochodzenie i poszukując winnych. [...] Kolegia powiatowe, do których wpływa wniosek o ukaranie któregoś z dyrektorów - na ogół miejscowych notabli - z reguły traktują sprawę tolerancyjnie i chętnie szukają wybiegów formalnych [...] by się od potrzeby rozstrzygania sprawy uwolnić. Milicja? Dotąd się tego rodzaju sprawami nie zajmuje" 88 .

$\mathrm{Na}$ inne strategie utrudniające kontrolę zanieczyszczeń wody wskazywał, na przykładzie Górnego Śląska, Tadeusz Kijonka: „A prawdziwy stan ścieków oraz ich ilość są trudne do ustalenia. Nim bowiem inspektor wodny dotrze do dyrekcji i uzyska zezwolenie na dokonanie kontroli - odpowiednia komórka zostaje uprzedzona i obraz właściwy ukryty. Ponadto przemysł z zasady odprowadza ścieki w porach niemożliwych do kontroli: nocą, w niedziele, w czasie deszczu. Wówczas następuje nagłe spuszczenie zbiorników i potężne masy zanieczyszczeń wędrują do rzek. Tego rodzaju UDERZENIA są najniebezpieczniejsze"89.

Strategie przedsiębiorstw w sprawie odpowiedzialności za zanieczyszczenia wód były zróżnicowane. Część z nich podejmowała wysiłki, aby usprawnić lub wybudować urządzenia do oczyszczania ścieków. Działo się tak szczególnie w takich przypadkach, gdy napływająca do nich rzekami woda była na tyle zanieczyszczona przez korzystające z niej wcześniej zakłady przemysłowe, że nie nadawała się do procesów produkcyjnych. Dokonując kalkulacji kosztów, część kierownictw zakładów dochodziła jednak do wniosku, że uiszczanie naliczanych okresowo kar jest bardziej opłacalne niż montowanie kosztownych i nie zawsze skutecznych urządzeń do oczyszczania ścieków. Wyjątkowo duże kary mogły

\footnotetext{
${ }^{87}$ AAN, NIK II, 52/14, Sprawozdanie..., s. 253.

${ }^{88}$ A. Zawieruszanka, Wodę wyżej!, „Prawo i Życie” 1967, nr 18, s. 1 i 5.

89 T. Kijonka, Wody bez życia, „Poglądy” 1965, nr 16, s. 7.
} 
spowodować, że dotknięte nimi zakłady przestawały w ogóle je płacićc ${ }^{90}$, ale z drugiej strony skłaniały dyrekcje przynajmniej niektórych trucicieli do instalowania odpowiednich urządzeń ${ }^{91}$.

W tej sytuacji można stwierdzić, że zatruwanie rzek ściekami, pochodzącymi zarówno z zakładów zużywających wodę, jak też komunalnych, było na porządku dziennym. O prawdziwości tego stwierdzenia przekonują informacje o powszechności katastrof i klęsk ekologicznych w ówczesnej Polsce. Świadczy o tym chociażby poniższe zestawienie, dotyczące tylko roku 1967.

Tabela 3. Przypadki szkodliwego zanieczyszczenia wód w 1967 r. według województw

\begin{tabular}{|l|c|}
\hline \multicolumn{1}{|c|}{ Województwo } & Liczba przypadków \\
\hline białostockie & 11 \\
\hline bydgoskie & 9 \\
\hline gdańskie & 20 \\
\hline katowickie & 20 \\
\hline koszalińskie & 6 \\
\hline kieleckie & 4 \\
\hline krakowskie & 32 \\
\hline lubelskie & 11 \\
\hline tódzkie & 10 \\
\hline m. Łódź & 4 \\
\hline olsztyńskie & 12 \\
\hline
\end{tabular}

${ }^{90}$ O strategiach zakładów pisał prof. Ryszard Manteuffel w 1968 r. (Trucie rzek i ekonomia, „Życie Warszawy” 1968, nr 13, s. 3). Twierdził w nim, że przez długi czas zakłady zanieczyszczające rzeki ściekami ponosiły odpowiedzialność cywilną i to tylko teoretyczną. „W najgorszym więc przypadku zakład przemysłowy mógł wybierać drogę, która była dla niego tańsza: albo ścieki oczyszczać, albo płacić za szkody, które one powodują. Zazwyczaj drogą tańszą była ta druga. [...] Znana jest poza tym praktyka różnych zakładów przemysłowych, które odszkodowania płacone za szkody spowodowane przez ścieki fabryczne, włączają do planów techniczno-ekonomicznych po stronie kosztów, przerzucając ten koszt na odbiorców swych towarów, a więc bezpośrednio na obywateli kraju, którzy i tak już cierpią z powodu zatrucia wód”. Manteuffel zwracał uwage na rzadkie przypadki stosowania odpowiedzialności karnej wobec sprawców zanieczyszczenia.

${ }^{91} \mathrm{~W}$ ówczesnej prasie podawano przykłady takich zakładów (m.in. Zakłady Chemiczne „Oświęcim”, Zakłady Chemiczne „Blachownia”, kopalnie węgla kamiennego „Łagiewniki”, „Szombierki”, „Zabrze”, „Zofiówka”). Zob. W. Eysymontt, Woda i prawo, „Tygodnik Demokratyczny” 1970, nr 23, s. 4 . 


\begin{tabular}{|l|c|}
\hline opolskie & 19 \\
\hline poznańskie & 6 \\
\hline rzeszowskie & 15 \\
\hline szczecińskie & 6 \\
\hline warszawskie & 7 \\
\hline m. Warszawa & 10 \\
\hline wrocławskie & 18 \\
\hline m. Wrocław & 6 \\
\hline zielonogórskie & 6 \\
\hline Razem & 232 \\
\hline
\end{tabular}

Źródło: obliczenia własne na podstawie: AAN, CUGW 910, b.pag.

To w 1967 r. (w nocy z 12 na 13 grudnia) wydarzyła się jedna z największych w latach sześćdziesiątych takich katastrof. W wyniku przerwania zapory wodnej stawów wód posadzkowych kopalni „Konrad” w Iwinach koło Bolesławca zalanych zostało sześć wsi. Uszkodzeniu uległo ponad 240 budynków mieszkalnych i 400 obiektów gospodarczych. Śmierć poniosło 18 osób. Zanieczyszczone metalami ciężkimi i chlorkami ścieki poflotacyjne przez 4,5 godziny płynęly wodami Bobrzycy, powodując zamarcie życia biologicznego, w tym masowe śnięcie ryb. Najtrudniejsza sytuacja wytworzyła się od ujścia rzeki Bóbr do ujścia Nysy Łużyckiej ${ }^{92}$.

Nie była to jedyna katastrofa ekologiczna w tym roku. 28 lipca nastąpiło szkodliwe zanieczyszczenie rzeki San przez Zakłady Płyt Pilśniowych w Przemyślu, 8 sierpnia - rzeki Wisłoki przez Zakłady Chemiczne „Gamrat” w Krajowicach koło Jasła, co spowodowało masowe śnięcie ryb i zagrożenie dla ludzi i zwierząt, korzystających nie tylko z wody Wisłoki w rejonie Dębicy i Mielca, ale i również zlewni Wisły ${ }^{93}$.

CUGW w uzgodnieniu z Głównym Urzędem Statystycznym (GUS) zebrał od WGWiOP informacje, z których wynikało, że od 1 stycznia do 30 września

\footnotetext{
92 AAN, Prokuratura Generalna PRL (dalej: PG), 15/66, Notatka informacyjna, Warszawa, 15 XII 1967, b.pag.; AAN, PG, 15/65, Sentencja wyroku wydanego przez Sąd Wojewódzki we Wrocławiu 14 IV 1970, b.pag.; AIPN, BU 0126/454, Sprawozdania z działań operacyjno-politycznych jednostek służby bezpieczeństwa województwa wrocławskiego za rok 1967, s. 20. Zob. również reportaż Przemysława Semczuka, Błotna fala, w: idem, Zatajone katastrofy PRL, Warszawa 2011, s. 77-84 (autor pomija wątek zanieczyszczenia środowiska spowodowanego przez przerwanie zapory w Iwinach). Według jego ustaleń w katastrofie, oprócz 18 ofiar śmiertelnych, zostało rannych blisko 570 osób.

${ }^{93}$ AAN, CUGW, 69, t. V, Informacja Głównego Inspektora Ochrony Wód Wiceprezesa CUGW w sprawie przypadków zanieczyszczenia wód w 1967 r., 9 XI 1967, b.pag.
} 
1967 r. 221 zakładów z ogólnej liczby 13 tys. pobierających wodę i odprowadzających ścieki spowodowało 214 przypadków szkodliwego zanieczyszczenia wód, w tym zatrucia wywołane zrzutem do wód substancji toksycznych. Najczęściej „truły” rzeki zakłady podległe Ministerstwom: Przemysłu Spożywczego i Skupu (50 zakładów), Przemysłu Chemicznego (27), Gospodarki Komunalnej (24), Przemysłu Lekkiego (23), Przemysłu Ciężkiego (17). W ujęciu przestrzennym zanieczyszczenia koncentrowały się na południu Polski. W województwie krakowskim 32 zakłady szkodliwie zanieczyściły wody 25 rzek, w tym sześciu na całej długości; w województwie wrocławskim (łącznie z Wrocławiem): 24 zakłady - 18 rzek, w tym pięć w całym ich biegu. Powyższe przypadki nie obejmowały zanieczyszczenia wód przez przedsiębiorstwa, które na podstawie art. 166 prawa wodnego zwolnione były z odpowiedzialności karnej, o ile nie przekroczyły ilości i składu cieków ustalonych na dzień 9 lutego 1961 r. W tej grupie znalazły się zakłady gospodarki komunalnej oraz kilka tysięcy przedsiębiorstw, które w dniu wejścia w życie przepisów prawa wodnego nie posiadały wymaganych urząadzeń do oczyszczania ścieków. Ich ujemny wpływ na stan czystości wód powierzchniowych stał się dominujący, powodował bowiem zanieczyszczenia w takim stopniu, że wiele odbiorników zostało uznanych za kanały ściekowe, pozbawione życia biologicznego. Z tych względów, chociaż na terenie województw katowickiego i krakowskiego zanotowano w 1967 r. liczne nowe przypadki szkodliwego zanieczyszczenia wód, nie były one tak widoczne, jak w innych województwach, gdzie trwały stan zanieczyszczenia był mniejszy ${ }^{94}$.

Cytowane przykłady z roku 1967 wyraźnie pokazują, jaki był mechanizm zanieczyszczania wód w tym okresie i jakie były bariery w jego ograniczaniu.

A katastrofy i klęski ekologiczne zdarzały się nie tylko wtedy. W analizowanych materiałach źródłowych możemy znaleźć dużo więcej informacji o mniejszych lub większych podobnych wydarzeniach związanych z zanieczyszczeniem środowiska.

Największym trucicielem Odry były wzmiankowane już Nadodrzańskie Zakłady Przemysłu Organicznego (NZPO) „Rokita”. Zanieczyszczenia Nysy powodowały Zakłady Celulozowo-Papiernicze w Przyłęku; tylko w jednym z wielu przypadków, 9 czerwca 1959 r., z powodu wpuszczonych do tej rzeki ścieków zginęło ponad 6 ton ryb, w tym większość łososi hodowanych przez Polski Związek Wędkarski od 1955 r. Przepływająca przez Białystok rzeka Biała była kanałem, do którego odprowadzane były ścieki wszystkich miejscowych zakładów przemysłowych. Masowe zatrucia ryb powtarzały się w rzece Supraśl, dopływie Narwi. Wisła aż do Sandomierza zatruwana była przez spływy ścieków z zakładów chemicznych w Oświęcimiu ${ }^{95}$.

\footnotetext{
${ }^{94}$ AAN, CUGW, 69, t. V, Informacja Głównego Inspektora Ochrony Wód Wiceprezesa CUGW w sprawie przypadków zanieczyszczenia wód w 1967 r., 9 XI 1967, b.pag.

${ }^{95}$ AAN, MŻiGW, 59, Cz. Wdowiak, Prawna ochrona wód..., b.pag.
} 
W styczniu 1964 r. zaobserwowano na Bugu znaczne ilości śniętych ryb płynące z prądem do Zalewu Zegrzyńskiego. Przyczyną był niedostatek tlenu w rzece spowodowany pokrywą lodową o grubości średnio $40 \mathrm{~cm}$ przy jednoczesnym zwiększeniu zanieczyszczeń organicznych zużywających tlen w procesie mineralizacji. Wiele zakładów odprowadzało ścieki do Bugu w znacznych ilościach wskutek braku lub niewłaściwej eksploatacji urządzeń do oczyszczania. Wśród tych przedsiębiorstw największe ładunki zanieczyszczeń odprowadzane były w czasie trwania kampanii buraczanej z cukrowni: Strzyżów, Wożuczyn, Werbkowice i Sokołów Podlaski ${ }^{96}$.

Zatruwanie niektórych rzek przez zakłady przemysłowe w latach sześćdziesiątych było zjawiskiem permanentnym. Co więcej, owe zanieczyszczenia miały swoją „specyfikę" regionalną związaną z dominacją zakładów określonego typu i branży. W województwie białostockim były to głównie spółdzielnie mleczarskie, niedostatecznie oczyszczające odprowadzane ścieki. W województwie bydgoskim wśród „trucicieli” dominowały cukrownie. Na Górnym Śląsku największe zanieczyszczenia powodowały oczywiście kopalnie węgla kamiennego odprowadzające do rzek zanieczyszczone wody dołowe, poflotacyjne i popłuczkowe. Tomaszowskie Zakłady Włókien Sztucznych w Tomaszowie z powodu braku urządzeń oczyszczających systematycznie zanieczyszczały Pilicę, powodując permanentne straty w rybostanie i nieprzydatność wód tej rzeki do celów komunalnych w Spale, Inowłodzu i Teofilowie. Wzmiankowane już zatruwanie Wisłoki przez Zakłady Chemiczne „Gamrat” stanowiło stałe zagrożenie ujęć wodnych dla Dębicy i Mielca przez związki fenolowe ${ }^{97}$.

Z danych zebranych w $1966 \mathrm{r}$. przez NIK wynikało, że straty w rybostanie wywołane zanieczyszczeniem wód w latach $1960-1965$ z powodu wytrucia ryb wzrosły o $177 \%$ i wyniosły w 1965 r. 1359 ton. Tylko z tego powodu rybactwo i wędkarstwo poniosło w 1966 r. szkody na sumę 21339 tys. zł, podczas gdy w 1960 r. - na $8 \mathrm{mln}$ zł. Na ogólną ilość 87700 ha wód bieżących ok. 30 tys. ha było w 1966 r. zanieczyszczonych w sposób szkodliwy dla ryb. Straty w gospodarce rolnej i leśnej okazały się wówczas niemożliwe do ustalenia z powodu nieprowadzenia takiej ewidencji ${ }^{98}$.

W analizowanych dokumentach źródłowych trudno natrafić na jakiekolwiek informacje, które wskazywałyby na podobne katastrofy ekologiczne związane z zanieczyszczeniem powietrza atmosferycznego. Nie udało się również odnaleźć jakichkolwiek danych statystycznych na temat stosowania systemu kar przewidzianych przez ustawę z $1966 \mathrm{r}$.

\footnotetext{
${ }^{96}$ AAN, CUGW, 69, t. I, Informacja Prezesa Centralnego Urzędu Gospodarki Wodnej dla Komisji Gospodarki Morskiej i Żeglugi Sejmu PRL w sprawie masowego śnięcia ryb w rzece Bug w styczniu 1964 r., b.pag.

${ }^{97}$ AAN, CUGW, 910, Przypadki szkodliwego zanieczyszczenia wód w 1967 r. według województw, b.pag.

${ }^{98}$ AAN, NIK II, 52/14, Sprawozdanie..., s. 211.
} 
W dotychczasowych rozważaniach na temat zanieczyszczeń środowiska pominięty został „wątek międzynarodowy” tego problemu. Zasługuje on na odrębną analizę. W tym miejscu ograniczę się tylko do jego zasygnalizowania głównie na podstawie dokumentów odnalezionych w zespole CUGW. Wydaje się, że stosunkowo największe napięcie wywołane zanieczyszczeniem rzek występowało w relacjach polsko-czechosłowackich. Skażenie wód Odry ściekami przemysłowymi przez stronę czechosłowacką stwierdzono w trakcie badań już w 1948 r.: „Dopływy Odry - na terenie górnośląskim wpływają bezsprzecznie na zanieczyszczenie wód odrzańskich, nie są jednak wyłącznym źródłem zanieczyszczania wód, a jedynie podtrzymują pierwotne zanieczyszczenie Odry z terenów czechosłowackich tak, że jakość wód Odry ani się nie polepsza, ani też pogarsza na trasie Olza - Skorogoszcz. W każdym razie Śląsk nie jest, jak dotąd ogólnie przypuszczano, tym wyłącznym sprawcą stałego zanieczyszczania wód odrzańskich" 99 .

Co jakiś czas napięcia na tym tle zaostrzały się z powodu kolejnej klęski ekologicznej wywołanej zresztą nie tylko przez stronę czechosłowacką. Oto na przykład Ambasada Czechosłowacji w Warszawie w nocie informowała, że 30 listopada 1951 r. stwierdzono gromadne zatrucie ryb w dorzeczu rzeki Stenavy na terytorium Czechosłowacji. Przeprowadzone dochodzenia wykazały, że zatrucie ryb zostało spowodowane wpuszczeniem związków chemicznych do wody przez fabrykę przerabiającą len w Mieroszowie. Wyrządziło ono szkody majątkom państwowym na terenie Czechosłowacji, w tym Państwowemu Przedsiębiorstwu Rybackiemu w Litomyślu ${ }^{100}$.

Odbywające się w latach sześćdziesiątych spotkania na szczeblu pełnomocników rządów PRL i Czechosłowacji w sprawie uregulowania kwestii zanieczyszczeń były trudne i nie przyniosły satysfakcjonujących rozwiązań ${ }^{101}$. Między innymi w trakcie ósmych rokowań pełnomocników rządu PRL i rządu CSRS do spraw gospodarki wodnej na wodach granicznych (w dniach 31 maja - 7 czerwca $1966 \mathrm{r}$. w Gottwaldowie) strona polska nalegała na szybką poprawę przez CSRS stanu czystości wód rzeki Białej Głuchołaskiej w jej przekroju granicznym ze względu na potrzeby dostarczania wody pitnej dla ludności miast Głuchołazy i Prudnik ${ }^{102}$. Strona czechosłowacka unikała podejmowania bardziej konkretnych zobowiązań w tych sprawach. W roku 1966 r. doszło również do pierwszych rokowań na temat

\footnotetext{
99 W. Mroziński, E. Niedzielowa, A. Sobota, Badanie prób wody Odry w 1948 r., „Gaz, Woda i Technika Sanitarna" 1949, nr 11, s. 361-362.

100 AAN, PKPG, 6305, Ambasada CSR w Warszawie do MSZ [b.d.], b.pag.

${ }^{101}$ AAN, CUGW, 665, Informacja CUGW o aktualnym stanie i zadaniach w przedmiocie ochrony wód przed zanieczyszczeniem. Materiały na konferencję u wiceprezesa Ministrów Obywatela Zenona Nowaka, Warszawa, czerwiec 1965, k. 10.

${ }^{102}$ AAN, CUGW, 509, Sprawozdanie z działalności CUGW za rok 1966, k. 61-62.
} 
gospodarki wodnej na wodach granicznych z ZSRR i NRD w oparciu o zawarte umowy międzynarodowe ${ }^{103}$.

Można zatem stwierdzić, że co prawda w latach sześćdziesiątych został podjęty wysiłek stworzenia prawno-organizacyjnych podstaw ochrony wód i powietrza przed zanieczyszczeniem, zwiększone zostały również nakłady na ten cel, ale osiągnięte efekty (z przyczyn już wcześniej wskazanych) były bardzo ograniczone.

\section{II.5. Zanieczyszczenie środowiska jako problem społeczeństwa: w poszukiwaniu początków świadomości ekologicznej ${ }^{104}$}

Czy coraz gorszy stan podstawowych składników środowiska naturalnego był problemem ważnym dla społeczeństwa polskiego w okresie gomułkowskim? Czy możemy stwierdzić, że wówczas pojawiły się elementy świadomości ekologicznej - a jeżeli tak, to jakie były jej przejawy?

Pewnych elementów odpowiedzi na tak sformułowane pytania udziela ówczesna prasa. Dyskurs o zagrożeniach środowiska naturalnego i o jego aktualnym stanie rozszerzał się, obejmując nie tylko periodyki specjalistyczne, ale również gazety i czasopisma adresowane do szerokiego odbiorcy. Już w latach 1956-1961

${ }^{103}$ Ibidem, k. 2-6. Ciekawym wątkiem, który warto rozwinąć w toku dalszych badań, były próby wypracowania wspólnych zasad polityki w zakresie ochrony środowiska przez kraje bloku wschodniego w ramach Rady Wzajemnej Pomocy Gospodarczej. Świadczą o tym udostępnione już historykom akta z tzw. Kancelarii Tajnej Urzędu Rady Ministrów. Można w nich odnaleźć m.in. sprawozdanie wiceprezesa CUGW mgr. inż. Wiesława Janiszewskiego, przewodniczącego delegacji polskiej na posiedzeniu grupy roboczej przedstawicieli krajów - członków RWPG w sprawie ochrony wód przed zanieczyszczeniem, która obradowała w Moskwie od 30 czerwca do 6 lipca $1961 \mathrm{r}$. W trakcie obrad doszło do istotnych rozbieżności w sprawie ustalenia podstawowych zasad umów między krajami - członkami RWPG o współpracy w zakresie czystości wód. Strony czechosłowacka i rumuńska wystąpiły przeciwko przyjęciu redakcji artykułu 1 odpowiedniego dokumentu o zobowiązaniach stron, zawierających umowę o niedopuszczeniu do zwiększania istniejącego stanu zanieczyszczeń powierzchniowych i podziemnych wód granicznych. Obie strony proponowały redakcję złagodzoną („o zobowiązaniu do podjęcia wysiłków dla niedopuszczenia do zanieczyszczeń"). Ich stanowisko znalazło wyraz w protokole. Delegacje obu państw dążyły do osłabienia również innych zobowiązań (m.in. nie zgodziły się na zapis zaproponowany przez stronę polską o pokryciu kosztów związanych z oczyszczeniem wód granicznych w przypadku ich zanieczyszczenia przez stronę naruszającą porozumienie). Zob. AAN, URM - Kancelaria Tajna, 2/437, Sprawozdanie polskiej delegacji, biorącej udział w posiedzeniu grupy roboczej przedstawicieli krajów - członków RWPG w sprawie ochrony wód przed zanieczyszczeniem, 10 VIII 1961, b.pag.

104 Określenie „świadomość ekologiczna” traktuję - zgodnie z polską tradycją badawczą - jako zespół informacji i przekonań o stanie środowiska i jego związkach z warunkami i jakością życia ludzi. Zob. T. Burger, Konflikt i współdziałanie. Świadomość ekologiczna i postawy społeczeństwa, w: Świadomość ekologiczna i społeczne ruchy „zielonych” w Polsce, red. W. Mirowski przy współpracy P. Glińskiego, Warszawa 1999, s. 36; idem, Świadomość ekologiczna społeczeństwa polskiego, Warszawa 2005, s. 10. 
można w nich odnaleźć liczne teksty krytycznie analizujące tę problematykę ${ }^{105}$. Ten nurt publicystyki był kontynuowany również w okresie późniejszym ${ }^{106}$. Należy jednak pamiętać, że cenzura prasy i autocenzura dziennikarzy miały bez wątpienia wpływ na ostateczny kształt tych publikacji.

W tej sytuacji, wobec braku odpowiednich badań naukowych, elementów odpowiedzi na postawione pytania można szukać w listach pisanych przez obywateli PRL do władz. Na potrzeby tego studium odpowiednia kwerenda została przeprowadzona w Archiwum Ośrodka Dokumentacji i Zbiorów Programowych TVP SA. Okazało się, że wiele tego typu korespondencji docierało do Polskiego Radia i Telewizji. Co ważne, duża część z nich to były listy zbiorowe, co świadczy o tym, że świadomość zagrożenia i poszukiwanie sposobów na jego zwalczanie nie były jednostkowe. Niektóre $\mathrm{z}$ nich zawierają informacje o tym, że ich nadawcy próbowali interweniować w wielu innych instytucjach, ale bezskutecznie. Ich motywem było najczęściej nie tylko (a nawet nie przede wszystkim) przekonanie o szkodliwości degradacji środowiska naturalnego jako takiego, ale zagrożenie dla zdrowia i życia ludzi (a zwłaszcza ich samych, rodzin i lokalnego środowiska), jakie opisywane zanieczyszczenia powodowały.

Na potwierdzenie tego stanowiska można odnaleźć liczne przykłady w zachowanych przekazach źródłowych. Datę 23 grudnia 1957 r. nosi skarga 43 pracowników Zakładów Koksochemicznych „Bolesław Chrobry” w Wałbrzychu, w której opisywali oni skutki funkcjonowania tam „niewielkiej fabryczki” kwasu siarkowego: „Tumany brunatnego dymu rozwłóczą się po całym terenie i spowodowały całkowite zniszczenia otaczającej przyrody. W ciągu kilku lat drzewa, krzewy, trawa, nawet odporne zielska wyschły zupełnie. W ciągu lata zakład otoczony nagimi szkieletami drzew $\mathrm{z}$ wyciągniętymi ku niebu ramionami gałęzi wywiera ponure i przygnębiające wrażenie. A ludzie? Ludzie pracują i cierpią. Chronić się przed zatrutym powietrzem nie mogą, bo nie ma jak, a szkodzi ono zdrowiu, bardzo chorują robotnicy na nieżyt dróg oddechowych, wypadanie włosów, zapaleń [sic!] skóry, co stwierdziła komisja z udziałem lekarza zakładowego protokołem z dnia 10 grudnia 1956 r.”'107. List zbiorowy o podobnej treści (w sprawie zapylenia Krakowa przez Fabrykę Supertomasyny „Bonarka”) dotarł

105 J. Ziętek, Zieleń i woda dla mieszkańców śląskich miast, „Trybuna Ludu” 1954, nr 219, s. 3; T. Keller, Problem złej wody, „Tygodnik Demokratyczny” 1955, nr 49, s. 7; J. Jaruzelski, Otrute rzeki, „Życie Warszawy” 1958, nr 52, s. 3-4; R. Dobrzyński, Nie zabijaj Wisty, „Morze” 1959, nr 12, s. 4-5; I. Szenkowa, Cena zdrowia, „Służba Zdrowia” 1959, nr 9, s. 6; W. Dudziński, Czyste powietrze, „Życie gospodarcze” 1961, nr 18, s. 3.

${ }^{106}$ Zob. m.in.: J. Brysz, Ziemia łódzka fetorem płynąca, „Odgłosy” 1963, nr 8, s. 8; idem, Smog nad Łodzią, „Odgłosy” 1965, nr 22, s. 1; A. Bełzowa, Na Śląsku drzewa umierają stojąc, „Tygodnik Kulturalny” 1969, nr 26, s. 1, 9; Z. Trziszka, Ciemne niebo, „Tygodnik Kulturalny” 1970, nr 1, s. 1; J. Hennelowa, Czysta woda, czyste powietrze, „Tygodnik Powszechny” 1970, nr 40, s. 6; J. Tabencki, Miliony ton, „Przegląd Techniczny” 1967, nr 26, s. 10.

107 TVP ODiZP, 1050/24, t. 1, KdSR, Biuro Listów, Biuletyn nr 25, 3 IV 1958, k. 190. 
z Krakowa ${ }^{108}$. „Lokatorzy domów ul. Mikołowskiej przy kopalni Wujek” w marcu 1958 r. opisywali, jak glinianka koło ich osiedla została zasypana kamieniem, a następnie żużlem z kopalni, zawierającym związki siarki i palącym się, mimo chłodzenia go wodą. W efekcie następowało powolne spalanie „siarkowodoru, który jest szkodliwy dla zdrowia”. Oskarżając wymienionego z nazwiska inżyniera kopalni o zastosowanie tego procederu pisali: „Hitler truł ludzi w komorach gazowych, a ob. inż. Z. zrobił z nas królików doświadczalnych i truje nas powoli $\mathrm{w}$ mieszkaniach. Jak rano się wstaje to z bólem głowy i dziwnym uczuciem. Wymioty wyczerpują wnętrzności” ${ }^{109}$.

W innym liście pracownik Poznańskich Zakładów Chemicznych w lutym 1958 r. skarżył się do Polskiego Radia: „Warunki zdrowotne jakie są na naszym osiedlu są nie do opisania. Tuż przy naszym osiedlu znajduje się Fabryka Siarki w Poznaniu-Zegrze ul. Obotrycka. Nikt nie zastanawia się nad tym, że będzie szkodzić całemu osiedlu, że osiedle jest pozbawione owocu i warzyw przez wybuchy, które zdarzają się dwa razy w tygodniu a jakie są szkodliwe mogą potwierdzić wszyscy, którzy to widzą. Kiedy człowiek wróci z pracy to musi być zamknięty w mieszkaniu, gdyż przebywanie na powietrzu względnie otwieranie okien jest niemożliwe". Autor listu twierdził, że mieszkańcy osiedla pisali w tej sprawie do Ministerstwa Zdrowia, ale bez rezultatu. „Osiedle nasze jest tak zbuntowane, że dłużej nad sobą panować nie potrafią. Weźcie to sobie do serca, że jesteśmy też obywatelami Polski Ludowej i że trzeba nas też otoczyć opieką i warunkami, jakie

${ }^{108}$ Ibidem, List „Mieszkańców Krakowa” z lutego 1956 r. w sprawie zapylenia Krakowa przez Fabrykę Supertomasyny „Bonarka”, k. 189. Sprawa „Bonarki” stała się tematem publicystyki prasowej. Mirosława Okolska w reportażu zamieszczonym w „Polityce” w 1966 r. pisała o stanie środowiska wokół zakładu w latach pięćdziesiątych: „Drzewa jeszcze kwitły, ale już nie dawały owocu. Czarna choroba toczyła pomidory i fasolę. Na ziemię dniem i nocą opadał biały pył. Potem sady zaczęły powoli usychać, warzywa ginęły, a dachówka kruszyła się w palcach”. W 1953 r. po raz pierwszy jeden z okolicznych mieszkańców zdecydował się wnieść pozew do sądu przeciwko fabryce. Potem - ruszyła lawina: jeśli wierzyć autorce sądy zasądziły w 3600 sprawach przeciwko zakładom około 50 mln zł odszkodowania, co wymusiło instalację elektrofiltrów i ustanowienie etatu kierownika laboratorium do spraw ochrony powietrza. Zob. M. Okolska, Włączyć filtry, „Polityka” 16 IV 1966. Skargi na zatrucie powietrza wokół fabryki bynajmniej jednak wówczas nie ustały, o czym świadczy list mieszkańca Krakowa Edwarda Mrugały z 20 III 1972 r., skierowany do Komitetu do Spraw Radia i Telewizji, w którym pisał, iż co prawda problem zanieczyszczeń w tym rejonie został rozwiązany tylko czasowo, gdyż „19 III 72 roku Supertomasyna zaczęła ponownie zasypywać swoim białym żrącym proszkiem”. W odpowiedzi Zjednoczenie Przemysłu Nieorganicznego w Warszawie informowało, że w ciągu dziesięciu lat produkcja tomasyny w „Bonarce” zwiększyła się o 10\%, a emisja pyłów zmalała o 75\%. Od 1959 r. zakłady zostały wyposażone w elektrofiltry. Jednocześnie pisano, że sumaryczne zapylenie w okolicach ul. Uroczej (gdzie mieszkał autor skargi) „roku 1972 znacznie wzrosło”. Zob. ODiZP, 1703/1, t. 36, List E. Mrugały, b.pag.; ibidem, Zjednoczenie Przemysłu Nieorganicznego do Biura Listów Komitetu do spraw Radia i Telewizji „Polskie Radio i Telewizja”, Warszawa, 19 V 1972, b.pag.

${ }^{109}$ ODiZP, 1050/24, t. 1, KdSR, Biuro Listów, Biuletyn nr 37, 17 V 1958, b.pag. 
posiadać powinien każdy obywatel. Wydaje nam się, że łatwiej przenieść to jedno zabudowanie - fabrykę, aniżeli zagospodarowane osiedle"110.

Szczególnie dramatyczny był list dotyczący zanieczyszczenia powietrza na terenie Górnego Śląska, wysłany z Chorzowa 19 marca 1958 r. przez nadawcę skrywającego się za inicjałami N.W. Jego autor konstatował: „Dla opisania tego zagadnienia zużyto już chyba litry atramentu, wypisano tony artykułów w prasie miejscowej, omawiano ją szeroko w audycjach radiowych, wyliczono dokładnie ile ton pyłu i sadzy spada dziennie na tereny poszczególnych miast śląskich, omówiono wszystkie ujemne skutki tego zjawiska dla zdrowia mieszkańców i... na tym koniec". Wydawałoby się rzeczą zupełnie bezsporną, że lepiej wydać pieniądze na elektrofiltry w zakładach przemysłowych, niż na tysiące łóżek szpitalnych dla ludzi poszkodowanych na zdrowiu. Nie można było też usprawiedliwić milczenia posłów ze Śląska w tych sprawach: „List mój zaprawiony jest może pewnym rozgoryczeniem, ale proszę się nie dziwić, ponieważ niedawno dowiedziałem się, że rozwija się u mnie rak w płucach, a tkanka nowotworowa powstała na skutek obłożenia zjadliwym pyłem pochodzącym z powietrza. Mnie już nic nie uratuje, mam wyrok śmierci, ale chodzi o tysiące moich następców, którzy nie chcą umierać z powodu karygodnego niedbalstwa naszych posłów. Dlatego głos mój jest jakby głosem zza grobu"111.

Podsumowując korespondencję na temat zanieczyszczenia środowiska, jaka napłynęła w latach 1956-1958, w Biuletynie Biura Listów Komitetu do spraw Radiofonii „Polskie Radio” stwierdzano, że świadczy ona „przede wszystkim o obojętności czynników kompetentnych do załatwiania tych spraw jak również o tendencji stałego odwlekania właściwego ich załatwienia". O inwestycjach $\mathrm{w}$ ochronę środowiska mówiło się coraz więcej, podejmowano odpowiednie uchwały, ale w minimalnym stopniu były one realizowane. Brakowało opracowanych metod działania, dokumentacji technicznej, a w szczególności nie było poważnych funduszy na te cele. „W związku z powyższym zakłady $\mathrm{z}$ reguły odkładają konieczne inwestycje $\mathrm{z}$ roku na rok, a próby tymczasowego zabezpieczenia przyrody i ludności przed szkodliwymi wyziewami, czy też trującymi ściekami - są niedostateczne”. „W listach tych, jak i w listach dotyczących zagadnienia BHP na zakładach przebija rozgoryczenie, że państwo nasze, które szczyci się troską o człowieka - w konkretnych wypadkach zapomina o nim, o jego zdrowiu"112.

Skargi na zatrucie wód i powietrza atmosferycznego pojawiały się również potem. W liście z 1959 r. mieszkanka Szczecina alarmowała: „Mieszkam w Śródmieściu. Szczecinianie piją wstrętną wodę z fenolem. Prasa wiele alarmowała

110 ODiZP, 1050/24, t. 1, KdSR, Biuro Listów, Biuletyn nr 37, 17 V 1958, b.pag.

111 ODiZP, 1050/24, t. 1, KdSR, Biuletyn nr 25, 3 IV 1958, b.pag.

112 ODiZP, 1050/24, KdSR, Biuletyn nr 37, 17 V 1958 dotyczący zanieczyszczenia powietrza i rzek przez zakłady przemysłowe, oraz bezpieczeństwa i higieny pracy w zakładach, k. 182. 
w ubiegłym roku na ten temat. Długi czas woziliśmy wodę z pomp, przed którymi oczywiście ustawiały się kilometrowe ogonki. Po pewnym czasie w prasie napisano, że woda nadaje się do picia, tzw. wodociągowa. W dalszym ciągu pijemy jednak tak bardzo szkodliwą dla organizmu wodę. Interesujemy się wszyscy tym, że zagranicą dzieją się takie, a nie inne rzeczy, że się o wiele rzeczy nie dba [...], ale sami nie widzimy, jak wiele krzywdy wyrządza się naszemu społeczeństwu. Dzieci mają być w przyszłości kalekami. Przecież dobrze jest nam wiadome, jak bardzo jest szkodliwy fenol. Atakuje wzrok, wątrobę, nerki i wiele innych narządów w naszym organizmie. Wiele konferencji już się odbyło na ten temat, ale jak dotąd nic się nie zmieniło. Jesteśmy po prostu skazani na powolne zatrucie"113.

W tym samym roku słuchacz Polskiego Radia opisywał katastrofę ekologiczną spowodowaną przez chemikalia wpuszczone do Brdy przez bydgoskie zakłady „Persil”. Na rzece pojawiły się ławice zatrutych ryb, łowionych „z gorliwością” przez dzieci i dorosłych: „Trucie ryb stało się w naszym województwie, a nawet w całym kraju nagminne; dla przykładu wytrucie ryb na Noteci przez Zakłady Sodowe w Mątwach koło Inowrocławia oraz wytrucie ryb na jeziorach pod Piechcinem czy na Nysie i Odrze"114.

Problemy z zatrutą wodą i powietrzem komplikowały się, gdy próby ich rozwiązania wiązały się z koniecznością interwencji poza granicami kraju. Tak było w przypadku tzw. awarii fenolowej we Wrocławiu 12 stycznia 1963 r. Wskutek ustania samooczyszczania Odry po zamarznięciu, spadku poziomu wody w Oławce, z której wodociągi wrocławskie częściowo czerpały wodę, nastąpiło przedostanie się do ujścia Oławy wód z Odry zanieczyszczonych fenolem. Awaria fenolowa została szybko zlikwidowana. Jednak gdy w wyniku niskich temperatur na terenie Czechosłowacji zamarzły wszystkie odfenolownie, ilość fenolu w Odrze zaczęła ponownie rosnąć i to tak, że dwutlenek chloru przestał być środkiem wystarczającym do jego neutralizacji. W końcu stycznia pojawił się znów w wodzie nieprzyjemny zapach i smak chlorofenolu. Sprawą zajęły się władze terenowe i lokalne, a wicepremierzy Piotr Jaroszewicz i Stefan Jędrychowski interweniowali u naszego południowego sąsiada. Gdy okazało się, że Czechosłowacja nie jest w stanie zapanować nad zrzutami fenolu, a całkowite przemarznięcie aż do dna rzeki Oławy nie pozwalało na czerpanie z niej wody - wprowadzono we Wrocławiu ograniczenie w jej zużyciu, eliminując całkowicie ujęcie powierzchniowe i ograniczając się do wody głębinowej. W mieście w okresie awarii fenolowej wystąpiła - wedle określenia zawartego w piśmie wyjaśniającym Prezydium MRN - „histeria” wśród mieszkańców. W celu jej przeciwdziałania władze zwracały się do miarodajnych osób i instytucji

113 ODiZP, 1050/28, KdSR, Biuletyn nr 12, 6 III 1959, H. Cz., zam. Szczecin, list z 29 I 1959, b.pag. ${ }^{114}$ ODiZP, 1475/2, KdSR, Biuletyn nr 36, Warszawa 3 VII 1959, List z 17 VI 1959, b.pag. 
o wydanie opinii o nieszkodliwości dla zdrowia tej ilości fenolu, którą zawierała woda wrocławska (co uzyskano) ${ }^{115}$.

Występujący już wcześniej w scharakteryzowanych listach motyw zatrucia powietrza atmosferycznego i jego skutków dla zdrowia i przyrody występuje również w skardze z 1966 r., dotyczącej rejonu Trzebini. Jej autor pisał: „Najwięcej dokucza oddział prażenia rudy cynkowej i tzw. «Trzebinia II», gdzie odbywa się rafinacja aluminium, przetopy złomu i inne. Wymownym dowodem szkodliwej działalności na organizmy ludzkie w tym rejonie jest duża ilość chorych dzieci i dorosłych. Choroby powszechne to choroba układu krążenia i rak. Wiele dzieci i dorosłych cierpi na różne schorzenia dróg oddechowych. Co mówić o zdrowiu mieszkańców, skoro nawet trawa tam nie rośnie. Rejon ten zaczyna przybierać krajobraz księżycowy (hałdy, nieużytki). $\mathrm{Z}$ jednej strony trujące gazy $\mathrm{SO}_{2}, \mathrm{SO}_{3}$, $\mathrm{HF}, \mathrm{H}_{2} \mathrm{~S}, \mathrm{CO}$ z okolicznych zakładów, których tutaj moc (wiele czynnych kotłowni o nisko sprawnych paleniskach, pracujących na mocno zasiarczonym węglu czarne dymy). $\mathrm{Z}$ drugiej znaczne zapylenie wtórne $\mathrm{z}$ hałd i dróg. Jeżeli do tego dodać fakt obniżenia się wód gruntowych spowodowanych przez kopalnie węgla «Siersza» i Zakłady Górnicze «Trzebionka» oraz liczne szkodliwe ścieki, duże zapylenie, potężny ruch samochodowy, ukształtowanie terenu, to źródło tych chorób staje się jasne. Nie bez wpływu jest także jakość wody pochodzącej ze złóż cynkowo-ołowianych o maksymalnym stopniu twardości. Najgorszym jest fakt, że po pracy oddycha się tym samym powietrzem, gdyż miasto nie ma żadnych stref ochronnych, jak również zielonych płuc (drzewa-parki)"116.

Przestawiony materiał źródłowy nie tylko poświadcza, że w Polsce gomułkowskiej istniały elementy świadomości ekologicznej. Poczucie zagrożenia środowiska naturalnego oraz zdrowia i życia ludzkiego z powodu zanieczyszczeń środowiska współistniało z przekonaniem o nieskuteczności środków podejmowanych przez instytucje państwowe w celu poprawy sytuacji. Mimo że nie doszło wówczas do instytucjonalizacji odrębnego i świadomego swych celów ruchu ekologicznego, to jednak można powiedzieć (za Józefą Hennelową ${ }^{117}$ ), że powstawała opinia społeczna, stwarzająca pewne formy nacisku na władze.

\section{Konkluzje}

1. W okresie tużpowojennym $\mathrm{w}$ dyskursie publicznym temat stanu środowiska naturalnego pojawiał się rzadko, zwykle w kontekście jego wpływu na kondycję biologiczną społeczeństwa wycieńczonego w wyniku przeżyć wojennych. Polityczna destalinizacja i „odwilż” październikowa, oprócz wielu innych skutków,

\footnotetext{
115 ODiZP, 1050/46, KdSR, Biuletyn Wewnętrzny nr 37, Warszawa, grudzień 1963, b.pag. 116 ODiZP, 1050/73, KdSRT, Biuletyn wewnętrzny nr 276, Warszawa, sierpień 1966, b.pag.

117 J. Hennelowa, op. cit., s. 1-2.
} 
spowodowała, że o degradacji środowiska mówiono i pisano coraz więcej i coraz krytyczniej w kręgach władzy, w niektórych zorganizowanych środowiskach społecznych i w prasie.

2. Coraz bardziej znany i odbijający się negatywnie na wynikach gospodarczych i zdrowotności stan środowiska naturalnego zmuszał władze do poszukiwania środków zaradczych. Podjęto działania legislacyjne i towarzyszące im zmiany organizacyjne. Najważniejsze z nich to: utworzenie Urzędu Ministra Żeglugi i Gospodarki Wodnej (1957), CUGW (1960) oraz terenowych struktur zajmujących się ochroną wód, uchwalenie ustawy prawo wodne (1962) i ustawy o ochronie powietrza atmosferycznego przed zanieczyszczeniem (1966).

3. W latach sześćdziesiątych podjęte zostały systematyczne badania zanieczyszczenia wód powierzchniowych oraz powietrza. Wykazały one, że w latach 1967-1970, w stosunku do okresu 1964-1967 stan czystości rzek i jezior uległ pogorszeniu. W tym samym okresie nastąpiło zmniejszenie emisji pyłów do atmosfery i zwiększenie emisji szkodliwych gazów.

4. Na ten stan wód i powietrza złożyły się przede wszystkim: nieskuteczność przyjętych rozwiązań prawnych (w tym systemu kar), niedostateczne nakłady inwestycyjne na urządzenia oczyszczające, które w dużej części były technologicznie przestarzałe, brak kwalifikowanych kadr ochrony środowiska.

5. Nieskuteczność podjętych działań w celu zahamowania degradacji środowiska naturalnego powodowała, że mniejsze lub większe katastrofy ekologiczne były w Polsce gomułkowskiej zjawiskiem powszechnym.

6. Analiza opinii wyrażonych w listach obywateli PRL do Polskiego Radia i publikacji prasowych wskazuje, że w analizowanym okresie istniały elementy świadomości ekologicznej ${ }^{118}$. Wielu Polaków werbalizowało w korespondencji wysyłanej do władz poczucie zagrożenia środowiska naturalnego oraz zdrowia i życia ludzkiego z powodu zanieczyszczeń środowiska, a jednocześnie dawało wyraz przekonaniu o nieskuteczności środków, podejmowanych przez instytucje państwowe w celu poprawy sytuacji.

\section{Pollution of air and water in Poland in the years 1945-1970 as a problem of the government and the society \\ (Abstract)}

Immediately after the war a discussion about the condition of the natural environment in Poland was held mainly in the specialist press that emphasised its degradation as especially dangerous for the society biologically and psychically wasted by experiences of the war. During the period of deStalinisation and political "thaw" after the 1956 October the subject of air and water pollution was

118 Oznacza to, że autor tego studium nie zgadza się z opinią Barbary Hicks (op. cit., s. 84), że jeszcze w latach siedemdziesiątych XX w. świadomość ekologiczna w Polsce była ograniczona do nielicznych ekspertów i prawników aktywnych w strukturach administracyjnych. 
more and more present in the press, but also in discussions of both the leaders of the state and some organised circles of the society. An increasingly well-known deteriorating state of the natural environment which adversely affected economic performance forced the government to search for remedies. As a result, new legal regulations were introduced with accompanying organisational changes. The most important of them were: the establishment of the Ministry of Navigation and Water Management (1957), Central Water Management Board (1960), and local structures responsible for the protection of waters from pollution, the introduction of the Water Law (1962), and the enactment of the Air Pollution Protection Act (1966). From 1960s on, systematic pollution tests of waters and air were carried on, which indicated that between 1967 and 1970 the condition of lakes and rivers deteriorated in comparison to the period of 1964-1967. In the same period there was an increased emission of greenhouse gases and reduced dust emissions. The main reasons for this were: the inefficacy of adopted laws (including a penalties system), insufficient financial investments in effective purification equipment, which was technologically outdated in its large part, the lack of qualified personnel specialised in environmental protection. There were, however, in the analysed period some elements of environmental awareness of people which were expressed, among other things, in letters sent by Polish citizens to the government.

\section{Bibliografia}

Atlas zanieczyszczenia rzek $w$ Polsce 1967, Warszawa 1971

Atlas zanieczyszczenia rzek $w$ Polsce 1970, Warszawa 1972

Atlas zanieczyszczenia rzek w Polsce 1971, Warszawa 1972

Bełzowa A., Na Śląsku drzewa umierają stojąc, „Tygodnik Kulturalny” 1969, nr 26

Bontemps S., W sprawie zanieczyszczeń wód, „Gospodarka Rybna” 1955, nr 2

Brysz J., Smog nad Łodziq, „Odgłosy” 1965, nr 22

Brysz J., Ziemia łódzka fetorem płynąca, „Odgłosy” 1963, nr 8

Brzeziński W., Ochrona prawna biologicznego środowiska człowieka, Warszawa 1971

Burger T., Konflikt i współdziałanie. Świadomość ekologiczna i postawy społeczeństwa, w: Świadomość ekologiczna i społeczne ruchy „zielonych” w Polsce, red. W. Mirowski przy współpracy P. Glińskiego, Warszawa 1999

Burger T., Świadomość ekologiczna społeczeństwa polskiego, Warszawa 2005

Cabejszek I., Koziorowski B., Malanowski Z., Stanisławska J., Charakterystyka higieniczno-sanitarna rzeki Wisly na odcinku Góra Kalwaria - Warszawa, „Gaz, Woda i Technika Sanitarna” 1956, nr 5

Chrzanowski F., Zanieczyszczenie wód śródlądowych województwa gdańskiego, „Gospodarka Rybna” 1956, nr 7

Delorme A., Antyekologiczna spuścizna totalitaryzmu. Polityka-gospodarka - środowisko naturalne, Kraków 1995

Dudziński W., Czyste powietrze, „Życie Gospodarcze” 1961, nr 18

Eysymontt W., Woda i prawo, „Tygodnik Demokratyczny” 1970, nr 23

Friszke A., Polska. Losy państwa i narodu 1939-1989, Warszawa 2003

Hennelowa J., Czysta woda, czyste powietrze, „Tygodnik Powszechny” 1970, nr 40

Hicks B., Environmental Politics in Poland. A Social Movement Between Regime and Opposition, New York 1996

Jaruzelski J., Otrute rzeki, „Życie Warszawy” 1958, nr 52

Jaroszyński A., Ochrona prawna zasobów naturalnych w PRL, Warszawa 1972.

Joszt, A. Ochrona rzek, „Gaz, Woda i Technika Sanitarna” 1952, nr 1

Krysiński J., Węzłowe problemy ochrony czystości wód (organizacyjne, techniczno-ekonomiczne i prawne), „Gospodarka Wodna” 1961, nr 10 
Leńkowa A., Aktualny stan zagrożenia środowiska w Polsce, w: Prawo a ochrona środowiska, red. L. Łustacz, Wrocław-Warszawa 1975

Manteuffel R., Trucie rzek i ekonomia, „Życie Warszawy” 1968, nr 13

Mroziński W., Niedzielowa E., Sobota A., Badanie prób wody Odry w 1948 r., „Gaz, Woda i Technika Sanitarna" 1949, nr 11

Ochrona powietrza atmosferycznego przed zanieczyszczeniem (przepisy i objaśnienia). Wedtug stanu prawnego na dzień 1 czerwca 1968, red. W. Tarasiewicz, Warszawa 1968

Ochrona wód powierzchniowych przed zanieczyszczeniem. Raport końcowy, t. 1, Wrocław 1971

Orzeszko E., System prawny ochrony środowiska $w$ Polsce, w: System ochrony środowiska w Polsce, red. A. Klich, Wrocław 1978

Podwysocki T., Brońmy czystej wody, „Przegląd Techniczny” 1968, nr 35

Pyłka-Gutowska E., Ekologia z ochroną środowiska. Przewodnik, Warszawa 1996

Dobrzyński R., Nie zabijaj Wisty, „Morze” 1959, nr 12

Rocznik Statystyczny GUS 1971, Warszawa 1971

Rudziński B., Zagadnienie dobrej wody, jako warunek dobrego zdrowia, „Gaz, Woda i Technika Sanitarna" 1946, nr 1

Semczuk P., Błotna fala, w: idem, Zatajone katastrofy PRL, Warszawa 2011

Stan zanieczyszczenia rzek w Polsce. Opracowanie syntetyczne, red. K. Matul et.al., Warszawa 1965

Surowiec S., Uwagi do ustawy o ochronie wód przed zanieczyszczeniem, „Gospodarka Wodna” 1961, nr 10

Szenkowa I., Cena zdrowia, „Służba Zdrowia” 1959, nr 9

Keller T., Problem złej wody, „Tygodnik Demokratyczny” 1955, nr 49

Kijonka T., Wody bez życia, „Poglądy” 1965, nr 16

Tabencki J., Miliony ton, „Przegląd Techniczny” 1967, nr 26

Trendota J, W sprawie właściwych metod ochrony wód przed zanieczyszczeniem ściekami, „Gaz, Woda i Technika Sanitarna" 1956, nr 4

Trziszka Z., Ciemne niebo, „Tygodnik Kulturalny” 1970, nr 1

Umiński T., Ekologia. Środowisko. Przyroda. Podręcznik dla szkół średnich, Warszawa 1996

Wiąckowski S., Ekologia ogólna, Bydgoszcz-Kielce 2008

Zawieruszanka A., Wodę wyżej!, „Prawo i Życie” 1967, nr 18

Ziętek J., Zieleń i woda dla mieszkańców ślaskich miast, „Trybuna Ludu” 1954, nr 219

Dariusz Jarosz, prof. dr hab., pracownik Instytut Historii im. Tadeusza Manteuffla PAN w Warszawie; specjalista w zakresie historii społecznej Polski w latach 1944-1989; autor m.in.: Polacy a stalinizm 1948-1956 (Warszawa 2000); „Masy pracujace przede wszystkim”. Organizacja wypoczynku w Polsce 1945-1956 (Warszawa-Kielce 2003); Mieszkanie się należy... Studium z peerelowskich praktyk społecznych (Warszawa 2010): współautor (z M. Pasztor), Afera mięsna: fakty i konteksty (Toruń 2004); (z G. Miernikiem): „Zhańbiona” wieś Okól: opowieści o buncie, Warszawa-Kielce 2016.

Kontakt: darjarosz@wp.pl 